\title{
MORPHOLOGY AND DISTRIBUTION OF RETINAL GANGLION CELLS PROJECTING TO DIFFERENT LAYERS OF THE DORSAL LATERAL GENICULATE NUCLEUS IN NORMAL AND SIAMESE CATS $^{1}$
}

\author{
AUDIE G. LEVENTHAL
}

\author{
Department of Anatomy, University of Utah School of Medicine, Salt Lake City, Utah 84132
}

Received November 9, 1981; Revised March 2, 1982; Accepted March 18, 1982

\begin{abstract}
Electrophoretic injections of horseradish peroxidase were made into physiologically characterized sites within the different layers of the dorsal lateral geniculate nuclei (LGNd) of normal and Siamese cats. The histochemical procedures used stained the cell bodies, dendrites, and axons of retrogradely labeled ganglion cells.

In both normal and Siamese cats, only $\alpha$ and $\beta$ ganglion cells are labeled by injections restricted to the A laminae. In normal cats, the $\alpha / \beta$ ratios (number of labeled $\alpha$ cells/number of labeled $\alpha+$ $\beta$ cells) resulting from injections into lamina $A$ increase from about 0.045 at $0.5 \mathrm{~mm}$ from the area centralis to about 0.12 in the far periphery. The $\alpha / \beta$ ratios observed outside of the area centralis in normal cats following injections into different parts of lamina A1 were lower at each eccentricity than those resulting from injections into corresponding parts of lamina $\mathrm{A}$. Also, the cell bodies and dendritic fields of $\alpha$ and $\beta$ cells projecting to lamina Al are somewhat larger than those projecting to corresponding parts of lamina $A$.

Outside of the area centralis, the relative numbers of $\alpha$ and $\beta$ cells projecting to Siamese lamina A are normal. However, $\alpha$ cells comprise an abnormally small proportion of ganglion cells projecting to the normal segments of Siamese lamina $\mathrm{Al}$ and an abnormally large proportion of cells projecting to the abnormal segments of lamina A1.

In Siamese cats, $\alpha$ and $\beta$ cells projecting to lamina AI are distributed continuously throughout virtually all of the ipsilateral and contralateral temporal retinas. Since large parts of the ipsilateral and contralateral hemifields are not represented in Siamese lamina A1, it seems that some of the retinal afferents to this lamina are being suppressed.

Injections into the $\mathrm{C}$ laminae of the LGNd show that the same morphological classes of ganglion cells project to these laminae in normal and Siamese cats. The classes projecting to the contralateral $\mathrm{C}$ laminae (laminae $\mathrm{C}$ and $\mathrm{C} 2$ ) include $\alpha, \beta, \gamma$, and $\epsilon$ as well as two other groups of cells referred to as $\mathrm{g} 1$ and g2 cells. $\gamma, \epsilon$, g1, and g2 cells project to the ipsilateral C lamina (lamina C1). In Siamese, but not in normal cats, examples of all of these types are found far into the contralateral temporal retina following injections involving lamina $\mathrm{C} 1$. This indicates that all classes projecting to the ipsilateral C lamina misproject in Siamese cats.
\end{abstract}

The retinas of a variety of species, including cats and monkeys, contain a number of different classes of retinal ganglion cells. The receptive field properties and morphologies of each of these classes are distinctive. The patterns of central projection of these classes are also distinctive, and different visual relays receive inputs from different complements of retinal ganglion cells. (For review, see Rodieck, 1979; Stone et al., 1979.)

The receptive field properties of cells in nuclei receiv-

${ }^{1}$ This work was supported by National Institutes of Health Grant PHS 1R01 EY03427. ing retinal afferents differ, reflecting, in large part, differences in their ganglion cell inputs. The receptive field properties of cells in different parts of nuclei receiving retinal afferents also differ from each other. For example, cells in lateral portions of the dorsal lateral geniculate nucleus (LGNd) subserve the peripheral retina, have larger receptive fields, and are more sensitive to rapid stimulus motion than are medial LGNd cells which subserve the central retina. Also, in the LGNd A laminae, the number of $\mathrm{Y}$ cells relative to $\mathrm{X}$ cells is higher in regions subserving the peripheral than in those subserving the central retina (Cleland et al., 1971; Hoffman et 
regions subserving the peripheral than in those subserving the central retina (Cleland et al., 1971; Hoffman et al., 1972; Creel and Giolli, 1976). Finally, in normal cats, cells in different layers of the LGNd receive afferents from different physiological classes of retinal ganglion cells (Cleland et al., 1976; Wilson et al., 1976); differences in the morphologies of the ganglion cells projecting to different layers of the LGNd also have been reported (Leventhal et al., 1980b).

LGNd also have been reported (Leventhal et al., 1980b).

In Siamese cats (Guillery, 1969), and in albino mammals in general (Sheridan, 1965; Lund, 1965; Creel, 1971a, b; Guillery and Kaas, 1971), the normal patterns of retinal ganglion cell projection are disrupted. In particular, many of the ganglion cells in the temporal retina, which, in normal cats, project to the ipsilateral hemisphere, project to the contralateral hemisphere in Siamese cats. As a result of this, the layers of the LGNd which normally receive inputs exclusively from the ipsilateral temporal retina receive a substantial projection from the contralateral temporal retina in Siamese cats (Guillery and Kaas, 1971). Whether the different laminae of the Siamese LGNd receive inputs from the same classes of ganglion cells and in the same proportions as in normal cats is not known.

The aim of this study was to compare the ganglion cells, in Siamese and normal cats, projecting to different layers of the LGNd as well as to parts of the LGNd subserving different regions of the retina.

\section{Materials and Methods}

Subjects. Twenty-two retinas from 11 adult normal cats and 12 retinas from 6 adult seal point Siamese cats provided the data for this study. The Siamese cats almost certainly came from different litters, since they were obtained at different times and from different sources by the vivarium at the University of Utah.

Surgery. Nembutal was administered intraperitoneally to induce and intravenously to maintain anesthesia. The animal's head was positioned in a stereotaxic apparatus and the skin, bone, and dura mater covering the appropriate regions were removed. The cortex was covered by a $4 \%$ solution of agar in saline as protection. Body temperature was monitored continuously and maintained automatically at 37 to $38^{\circ} \mathrm{C}$.

Neo-Synephrine was used to retract the nictitating membranes and atropine was employed to dilate the pupils. The corneas were protected from desiccation with zero power contact lenses and the optic discs and areae centrales were projected onto a tangent screen located $1.14 \mathrm{~m}$ from the cat's retina.

Electrophysiological recording. Prior to all horseradish peroxidase (HRP) injections, electrode penetrations were made into the LGNd in order to locate the representation of predetermined parts of the visual field in the different layers. Multiple and single unit activity was recorded with low impedance (1- to 3-megohm) microcapillary electrodes filled with $4 \mathrm{~m} \mathrm{NaCl}$. Neuronal responses were amplified conventionally, displayed on the oscilloscope, and monitored by ear. For all units and groups of units studied, response fields (the area of the visual field within which a visual stimulus elicited a response) were determined, and the distance from the center of each response field to the area centralis projection was measured. Since the animals were not paralyzed, each field was mapped twice and the areae centrales were plotted before and after each plot to verify that the eyes had not moved. Recordings from the visual cortex were carried out using procedures which have been outlined elsewhere (Leventhal and Hirsch, 1978; Dreher et al., 1980).

Electrophoretic injection. Once a satisfactory site was located, the electrode was removed and a microcapillary electrode filled with $10 \%$ HRP in Tris-HCl buffer ( $\mathrm{pH}$ 8.6) containing $1 \%$ dimethyl sulfoxide (DMSO) was lowered into the appropriate region. The correct position was confirmed by recording with this electrode prior to all injections. HRP was injected using currents of $-3 \mu \mathrm{A}$ ( $1.5 \mathrm{sec}$ on, $0.5 \mathrm{sec}$ off) for a period of 2 to $3 \mathrm{hr}$. The sites resulting from these injections appeared well localized and virtually black with HRP reaction product. This suggests that such long electrophoretic injections slowly deposit a high concentration of HRP over a small region. Shorter injections, regardless of the amount of HRP injected, did not give satisfactory labeling.

Histology and histochemistry. Animals were maintained for approximately $40 \mathrm{hr}$ following HRP injections. They then were anesthetized and perfused through the heart with $700 \mathrm{ml}$ of $35^{\circ} \mathrm{C}$ lactated Ringer's solution containing $0.1 \%$ heparin, followed by $1000 \mathrm{ml}$ of a $35^{\circ} \mathrm{C}$ solution of $1 \%$ paraformaldehyde and $2.5 \%$ glutaralde-

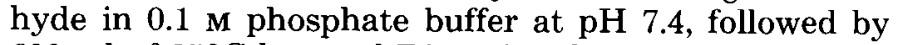
$600 \mathrm{ml}$ of $35^{\circ} \mathrm{C}$ lactated Ringer's solution containing 5\% dextrose. Brains were removed and the portions containing the injection sites were blocked and stored for 2 to 4 days in a $30 \%$ sucrose solution and then frozen-sectioned at $50 \mu \mathrm{m}$. Sections were collected in $0.1 \mathrm{M}$ Tris- $\mathrm{HCl}$ buffer ( $\mathrm{pH} 7.4$ ), reacted for $20 \mathrm{~min}$ in $0.1 \mathrm{~m}$ Tris buffer containing $0.03 \% p$-phenylenediamine dihydrochloride, $0.06 \%$ pyrocatechol, and $0.02 \% \mathrm{H}_{2} \mathrm{O}_{2}$ (PPD-PC reagent; Hanker et al., 1977), and transferred back into $0.1 \mathrm{M}$ Tris- $\mathrm{HCl}$ buffer.

Whole retinas were removed and reacted immediately after the perfusion. The best labeling was observed when the reaction was begun without delay. All retinas were rinsed in $0.1 \mathrm{M}$ Tris buffer ( $\mathrm{pH} 7.4$ ) for 5 min, incubated in $1 \%$ cobalt chloride (Adams, 1977) in Tris buffer containing $0.5 \%$ DMSO for $20 \mathrm{~min}$ at $35^{\circ} \mathrm{C}$, rinsed in Tris buffer at $35^{\circ} \mathrm{C}$ for $5 \mathrm{~min}$, rinsed in $0.1 \mathrm{M}$ phosphate buffer (pH 7.4) at $35^{\circ} \mathrm{C}$ for $5 \mathrm{~min}$, prereacted in the PPD-PC reagent containing $0.5 \%$ DMSO (without $\mathrm{H}_{2} \mathrm{O}_{2}$ ) at $35^{\circ} \mathrm{C}$ for $15 \mathrm{~min}$, reacted with fresh $\mathrm{PPD}-\mathrm{PC}$ reagent containing $0.5 \%$ DMSO (with $\mathrm{H}_{2} \mathrm{O}_{2}$ ) at $35^{\circ} \mathrm{C}$ for $20 \mathrm{~min}$, and rinsed in phosphate buffer for $30 \mathrm{~min}$. In retinas reacted in this fashion, the outlines of unlabeled cells are visible due to a light staining of the extracellular spaces (Fig. 1).

Cell body and dendritic field measurement. The cell bodies of filled cells were measured under the microscope using a calibrated eyepiece graticule and a $\times 100$ oil immersion objective. Cell body diameter was taken as the mean of the longest and orthogonally shorter axes.

Dendritic fields were measured under the microscope using a calibrated eyepiece graticule and a $\times 40$ oil immersion planapochromatic objective. For each dendritic field, the diameter along its longest axis was measured. Since the dendritic fields of most cells in Golgi material are approximately circular (Boycott and Wässle, 


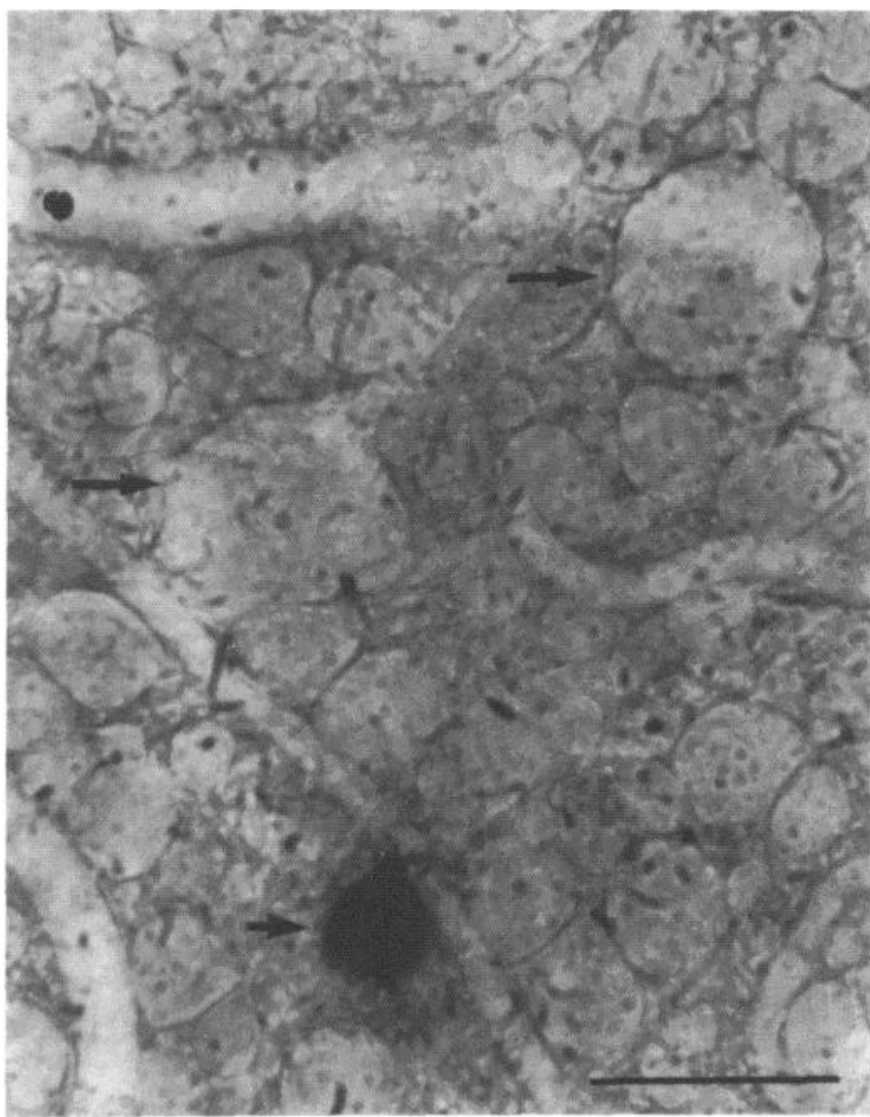

Figure 1. Profiles of unlabeled retinal ganglion cells in the ipsilateral temporal retina of Siamese cat S5. Unlabeled cells are visible due to staining of the extracellular spaces resulting from the HRP reaction protocol described under "Materials and Methods." The short arrow indicates a $\beta$ cell, located 1.5 $\mathrm{mm}$ temporal to the area centralis, labeled by an injection of HRP into the normal segment of lamina A1. The two long arrows indicate two unlabeled giant (presumably $\alpha$ ) ganglion cells. The photomicrograph was taken using a $\times 40$ planapochromatic objective (numerical aperture, 1.0) and a condenser setting of 0.22 . The low condenser setting improves the visibility of the unlabeled cells. Scale bar, $100 \mu \mathrm{m}$.

1974) and since I assume that not all of the cells in my material were completely filled, the long axis is likely to provide the most accurate indication of the dendritic field sizes of filled cells. However, it must be recognized that there is no absolute means of telling whether a cell is completely filled, and thus, the dendritic fields of some labeled cells may be larger than the measurements indicate. The data points in the figures are based on the 10 to 20 cells of each type that had the largest dendritic fields. The dendritic fields of these cells were approximately circular and the detail evident in these cells appeared to be comparable to that seen in Golgi material. Thus, these cells should provide the most accurate indication of dendritic field diameter.
Determination of ganglion cell density. The density of labeled ganglion cells was determined by counting cells within the regions of retina containing the highest density of labeling. Only regions of similar elevation were sampled. In the present study, injections were made into regions of the LGNd subserving parts of the retina 1 to $3 \mathrm{~mm}$ above the zero horizontal meridian. Initially, all labeled cells contained within a $0.25 \times 0.25 \mathrm{~mm}$ eyepiece grid were counted. Adjacent areas then were sampled in a spiral pattern centered upon the initial area until a sample of 200 to 300 cells was accumulated.

Cell classification. Ganglion cells have been classified as $\alpha, \beta, \gamma$ (Boycott and Wässle, 1974), and $\epsilon$ (Leventhal et al., 1980a). $\alpha$ cells have large cell bodies, large dendritic fields, and coarse axons; $\beta$ cells have medium size cell bodies, small dendritic fields, and medium gauge axons; $\gamma$ cells have small cell bodies, large dendritic fields, and fine axons; $\epsilon$ cells have medium size cell bodies, large dendritic fields, and fine to medium gauge axons. The dendritic morphology of each of these four classes is distinctive. Finally, it must be stressed that, in this study, the term " $\gamma$ cell" is used only to refer to those cells which clearly resembled the $\gamma$ cells illustrated by Boycott and Wässle (1974). Cells not fitting into the four established classes are described under "Results."

Statistics. Unless otherwise specified, the significance values given in the text are based upon a one-tailed $t$ test. Comparisons of cell body size and dendritic field diameter are based upon samples of 80 to 100 cells.

\section{Results}

\section{Normally pigmented cats}

In order to determine the relative numbers of the different types of retinal ganglion cells projecting to the laminated portion of the LGNd, electrophoretic injections of HRP involving all geniculate laminae receiving retinal afferents (laminae A, A1, C, C1, and C2; Hickey and Guillery, 1974) but apparently avoiding the optic tract were made successfully in one cat. A sample of 438 cells was studied in this animal. They were all more than $3 \mathrm{~mm}$ from the area centralis in the nasal retina and were in the regions containing the highest concentration of labeled cells.

The cells labeled in this animal included $\alpha(9 \%), \beta$ $(66 \%), \gamma(3 \%), \epsilon(3 \%)$, group 1 (g1; $13 \%)$, and group 2 (g2; $6 \%$ ) cells (Figs. 2, 3, and 10). G1 cells have medium size cell bodies, fine axons, and relatively large dendritic fields. The cell bodies of $\mathrm{g} 1$ cells are somewhat smaller (range, 17 to $24 \mu \mathrm{m}$ outside of the area centralis) than those of $\beta$ and $\epsilon$ cells (range, 19 to $31 \mu \mathrm{m}$ outside of the area centralis). The cell body sizes of $\beta$ and $\epsilon$ cells do not differ significantly (Leventhal et al., 1980a). The axons of g1 cells are finer than those of $\beta$ cells and not measurably different from those of $\epsilon$ cells. The dendritic fields of g1 cells are larger than those of $\beta$ cells and within the range

Figure 2. $\alpha$ cells stained by injections of HRP into the A laminae of the LGNd of normal and Siamese cats. A, Two $\alpha$ cells (Siamese cat) in the contralateral nasal retina projecting to lamina A; $B, \alpha$ cell (Siamese cat) in the contralateral temporal retina projecting to the abnormal segment of lamina $\mathrm{Al} ; C, \alpha$ cell (normal cat) in the contralateral nasal retina projecting to lamina $\mathrm{A}$; $D, \alpha$ cell (Siamese cat) in the ipsilateral temporal retina projecting to the normal segment of lamina A1; $E$, $\alpha$ cell (normal cat) in the ipsilateral temporal retina projecting to lamina A1. The $\alpha$ cells in $A$ to $E$ are all located between 5 and $7 \mathrm{~mm}$ from the area centralis and are at the same magnification. Scale bar, $100 \mu \mathrm{m}$. Note that, outside of the area centralis, there are no obvious morphological differences between $\alpha$ cells in normal and Siamese cats. 

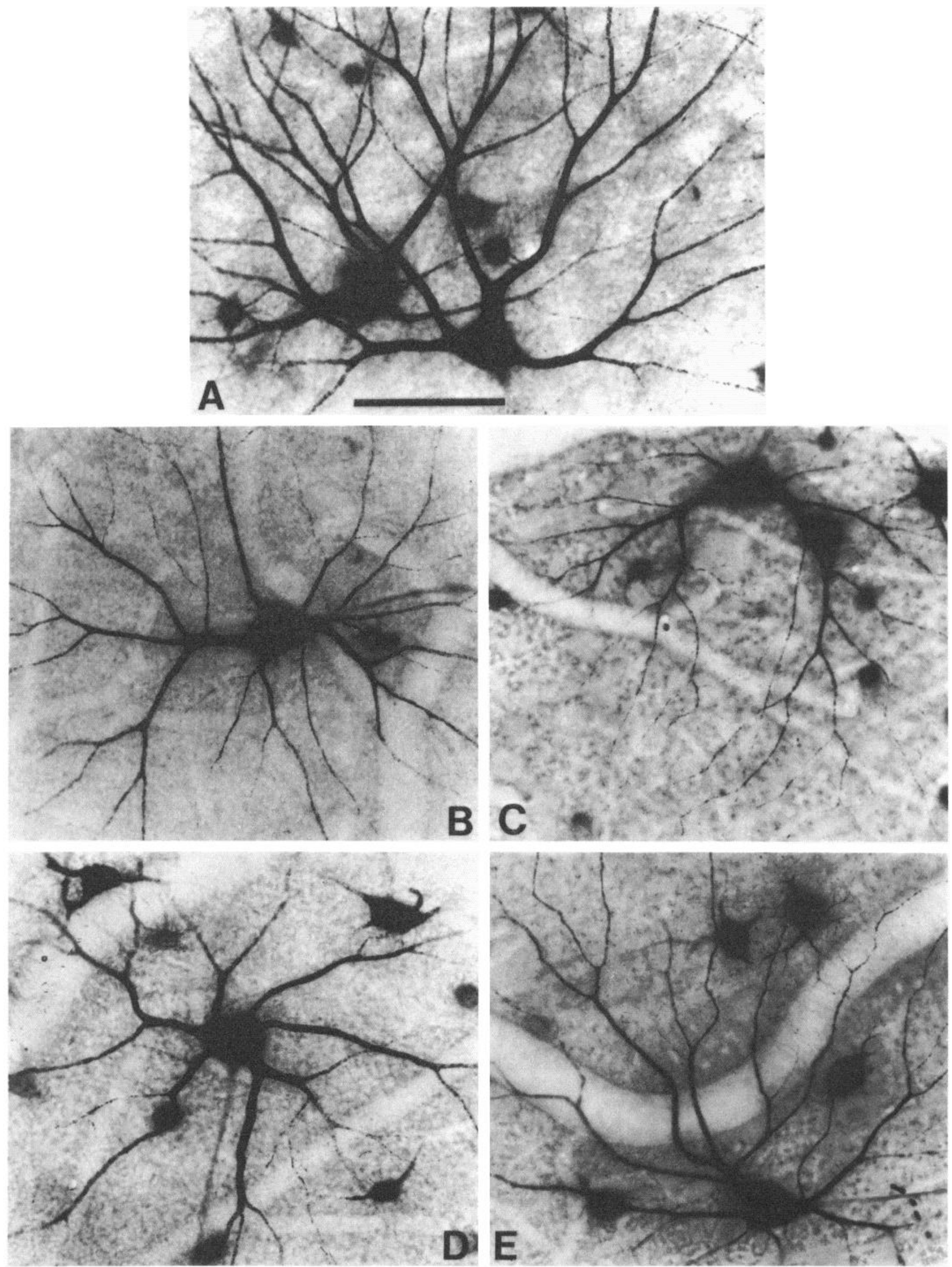

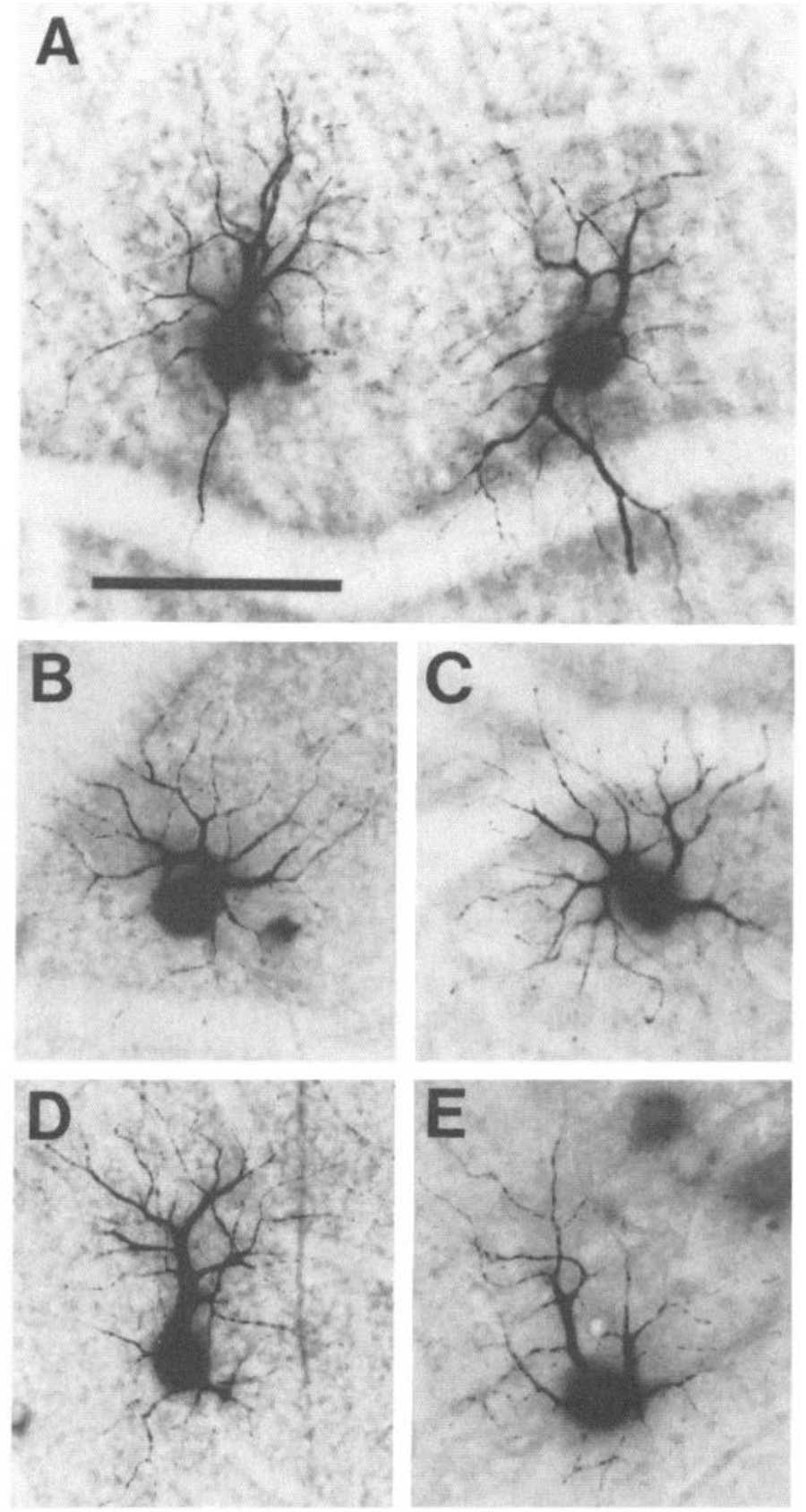

Figure 3. $\beta$ cells stained by injections of HRP into the A laminae of the LGNd of normal and Siamese cats. $A$, Two $\beta$ cells (normal cat) in the contralateral nasal retina projecting to lamina $A ; B, \beta$ cell (Siamese cat) in the contralateral temporal retina projecting to the abnormal segment of lamina $A 1 ; C, \beta$ cell (normal cat) in the ipsilateral temporal retina projecting to lamina $\mathrm{Al} ; D, \beta$ cell (Siamese cat) in the ipsilateral temporal retina projecting to the normal segment of lamina $A 1 ; E, \beta$ cell (Siamese cat) in the contralateral nasal retina projecting to lamina A. The $\beta$ cells in $A$ to $E$ are all located between 5 and $7 \mathrm{~mm}$ from the area centralis and are all at the same magnification. Scale bar, $100 \mu \mathrm{m}$. Notice that, outside of the area centralis, there are no obvious morphological differences between $\beta$ cells in normal and Siamese cats.

of those of $\epsilon$ cells. The dendritic branching patterns of $g 1$ cells vary and appear different from those of $\beta$ or $\epsilon$ cells. G1 cells may consist of a number of cell types which are distinct from the four established classes (A. G. Leven- thal, R. W. Rodieck, and B. Dreher, manuscript in preparation) and may, therefore, be regarded as a group of cells yet to be subdivided. Finally, g2 cells have small cell bodies within the $\gamma$ cell range ( 12 to $16 \mu \mathrm{m}$ ), large dendritic fields, and fine axons. The dendritic branching patterns of these cells vary and do not resemble the $\gamma$
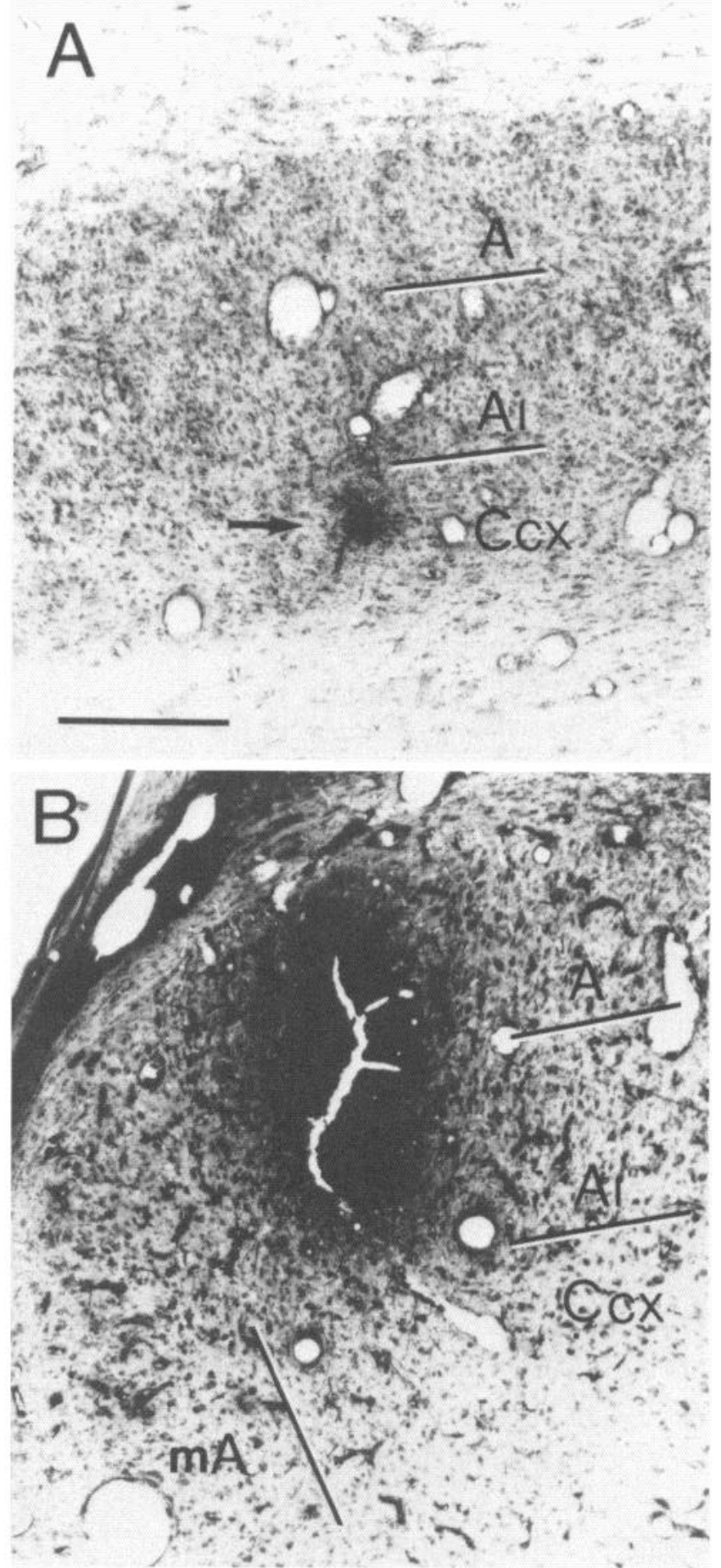

Figure 4. Spread of HRP resulting from two types of electrophoretic injections of HRP into the LGNd. $A$, Small injection site (arrow) confined to the normal cat's C laminae; $B$, large injection site involving the normal cat's A laminae. The approximate positions of laminar borders are indicated. Ccx refers to a composite of the $\mathrm{C}$ laminae and $m A$ refers to the monocular segment of lamina A. 
cells illustrated by Boycott and Wässle (1974). G2 cells also may account for more than one morphological cell type.

Differences in the ganglion cell inputs to the different geniculate laminae as well as to parts of the LGNd subserving different regions of retina are described below.

$A$ laminae. In normally pigmented cats, the A laminae of the LGNd receive inputs only from $\alpha$ (Fig. 2) and $\beta$ (Fig. 3) ganglion cells (Leventhal et al., 1980b). In order to study the retinal distributions of $\alpha$ and $\beta$ cells projecting to laminae $A$ and $A 1$, two different types of injections were made. The first type was made with a fine microcapillary electrode and resulted in a spread of HRP of a few hundred micrometers (Fig. 4A) (Leventhal, 1979). Injections of this type were relied upon primarily to provide information about which cell types project to which layers. The second type of injection was made with a coarser microcapillary electrode and resulted in larger sites (Fig. 4B). Typically, four to six of these larger electrophoretic injections of HRP were made into physiologically characterized sites spaced along the mediolateral extent of the A laminae. Injections into the binocular segment of the LGNd were made at the approximate location of the A/A1 border so that both of the A laminae were involved in the injection site. Inspection of the injection sites indicated that the spread of HRP around the injection sites in these cases extended throughout the width of both A laminae. As a result of these multiple injections, labeled cells were distributed from the vertical meridian to the far periphery in both the contralateral nasal retina (the cells projecting to lamina $\mathrm{A}$ ) and the ipsilateral temporal retina (the cells projecting to lamina A1). Nearly all labeled cells resulting from these injections were stained well enough to identify (Figs. 2 and 3) and, thus, the relative numbers of $\alpha$ and $\beta$ cells projecting to the A laminae were easily determined in these cases. A few lightly labeled small and medium size neurons were observed in cases where the secondary spread of HRP around the injection site reached the $C$ laminae. Presumably, these cells represent a projection to the $C$ layers from cell types other than $\alpha$ and $\beta$ (discussed below) since such lightly labeled cells were never observed in cases in which the injection sites were restricted entirely to the A laminae.

The regions of retina examined quantitatively following A laminae injections ranged from $0.5 \mathrm{~mm}$ from the area centralis to the far periphery. The area centralis itself was avoided in the quantitative analysis since injections labeling cells in this region have to be made very close to the border between the laminated LGNd and the medial interlaminar nucleus (MIN). The results of such injections are difficult to interpret since the ganglion cell inputs to the laminated LGNd and the MIN differ markedly (Mason, 1975; Dreher and Sefton, 1979; Rowe and Dreher, 1982). The central $0.5 \mathrm{~mm}$ of the retina subserves the central $2^{\circ}$ of visual angle, and the magnification factors in the LGNd are greatest for this region of the visual field. Thus, omitting this region of retina from the analysis should effectively eliminate cells projecting to the border region between the MIN and laminated LGNd.

In normally pigmented cats, there are a number of differences in the composition of ganglion cell inputs to laminae A and A1. These differences are only evident in corresponding regions of the nasal and temporal retina outside of the area centralis (Stone et al., 1980). The figures in this section illustrate the results for normal cats and are based on the results of the normal cat UC16. There were no obvious differences between this cat and the other normal cats which were studied.

As a result of injections into the A laminae of UC16, the density of labeled $\alpha$ and $\beta$ cells was higher at each eccentricity outside of the area centralis in the contralateral nasal retina than in the ipsilateral temporal retina ( $p<0.016$; binomial test) (Fig. 5A). The total number of labeled $\alpha$ and $\beta$ cells, at eccentricities between 2 and 7 $\mathrm{mm}$ from the area centralis, were, respectively, $25 \%$ and $15 \%$ lower in the ipsilateral temporal retina than in the contralateral nasal retina. At least for $\alpha$ cells, this difference is likely to reflect the difference in the overall densities of $\alpha$ cells in the nasal and temporal areas of cat retina since, in the regions studied, all large $(\alpha)$ cells appeared to be labeled.

Another difference between the crossed and uncrossed projection to the LGNd is evident if the relative numbers of labeled $\alpha$ and $\beta$ cells projecting to laminae A and A1 are compared. In particular, the $\alpha / \beta$ ratios (number of labeled $\alpha$ cells/number of labeled $\alpha+\beta$ cells) resulting from injections into lamina $A$ increase from about 0.045 at $0.5 \mathrm{~mm}$ from the area centralis to about 0.12 in the periphery (Fig. $6 A$ ). The $\alpha / \beta$ ratios observed following injections into different parts of lamina $\mathrm{A} 1$ were about $15 \%$ lower ( $p<0.016$; binomial test) at each eccentricity than those resulting from injections into corresponding parts of lamina A (Fig. 6).

It is unlikely that relatively fewer $\alpha$ cells were labeled in the temporal retina by injections involving both $\mathrm{A}$ laminae because the lower part of lamina $\mathrm{A} 1$, which receives a relatively strong $\mathrm{Y}$ cell input (according to Mitzdorf and Singer, 1977), was not involved in the injection site. This is because, in the present material, the outlines of unlabeled cells are visible due to the staining of the extracellular spaces (Fig. 1), and in the regions of the temporal as well as nasal retina sampled, all large cells appeared to be labeled. Moreover, although the axon terminals of retinal Y cells, which are likely to correspond to $\alpha$ cells (see "Discussion"), concentrate in the lower parts of laminae $\mathrm{A}$ and $\mathrm{A} 1$, the individual axonal arborizations of $Y$ cells are large and spread over most, if not all, of the lamina in which they terminate (Bowling and Michael, 1981; Stanford et al., 1981). Thus, virtually all $\alpha$ cells projecting to lamina A1 should have been exposed to HRP even if the injection site did not extend to the lowermost parts of the lamina. Nevertheless, it should be stressed that there is no way to rule out completely the possibility that some of the differences in the retinal projections to laminae $A$ and $A 1$ could have arisen artifactually due to uneven HRP uptake in lamina Al or uptake by cells terminating in lamina $\mathrm{C}$.

In normal cats, the sizes of $\alpha$ and $\beta$ cells projecting to lamina A differed from the sizes of those projecting to lamina A1. In regions of retina more than $2 \mathrm{~mm}$ from the area centralis, the cell bodies of $\alpha(p<0.001)$ and $\beta(p$ $<0.001$ ) cells projecting to lamina A1 were larger than the cell bodies of those projecting to lamina A (Fig. 7A). The dendritic fields of $\alpha(p<0.05)$ and $\beta(p<0.001)$ 

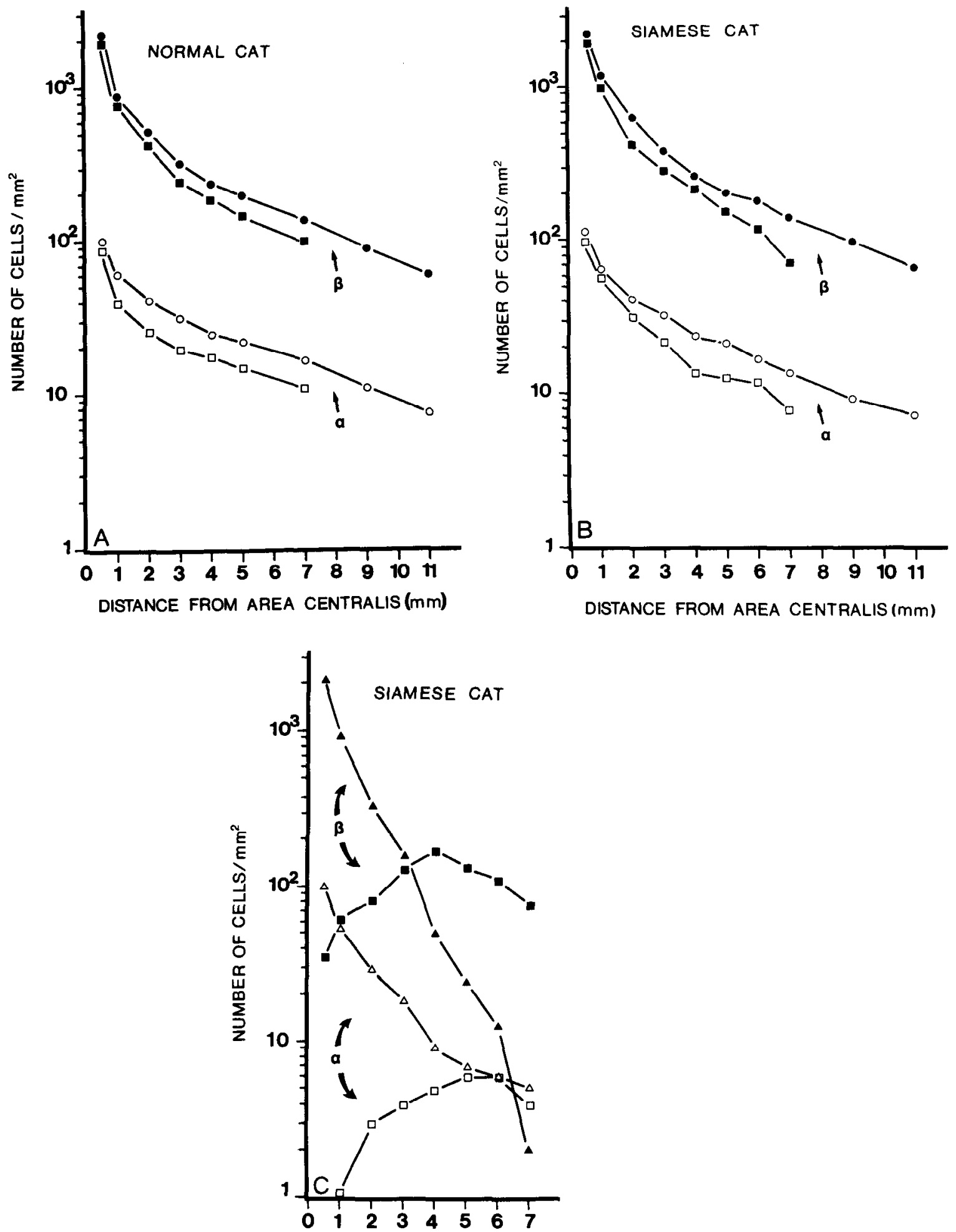

DISTANCE FROM AREA CENTRALIS $(\mathrm{mm})$

Figure 5. Spatial densities of $\alpha$ and $\beta$ cells projecting to the A laminae in normal and Siamese cats. $A$, Spatial densities of $\alpha$ (open symbols) and $\beta$ (solid symbols) cells labeled by multiple injections of HRP into laminae A and A1 of normal cat UC16. The squares indicate cells in the ipsilateral temporal retina projecting to lamina $\mathrm{A}$. The circles indicate cells in the contralateral nasal retina projecting to lamina $A$. In corresponding regions of the retina outside of the area centralis in normal cats, the spatial densities of $\alpha$ and $\beta$ cells projecting to lamina $A$ are greater than those of $\alpha$ and $\beta$ cells projecting to lamina A1. B, Spatial densities of $\alpha$ (open symbols) and $\beta$ (solid symbols) cells labeled by multiple HRP injections into laminae A and A1 of Siamese cat S5. The squares represent composite values for labeled cells located in corresponding parts of the ipsilateral and contralateral temporal retina. All of these cells projected to lamina $\mathrm{Al}$ in one hemisphere. The circles indicate cells in the contralateral nasal retina projecting to lamina A. Notice that, in corresponding regions of Siamese retina outside of the area centralis, the spatial densities of $\alpha$ and $\beta$ cells projecting to lamina $A$ are greater than those of $\alpha$ and $\beta$ cells projecting to lamina A1. $C$, Spatial densities 

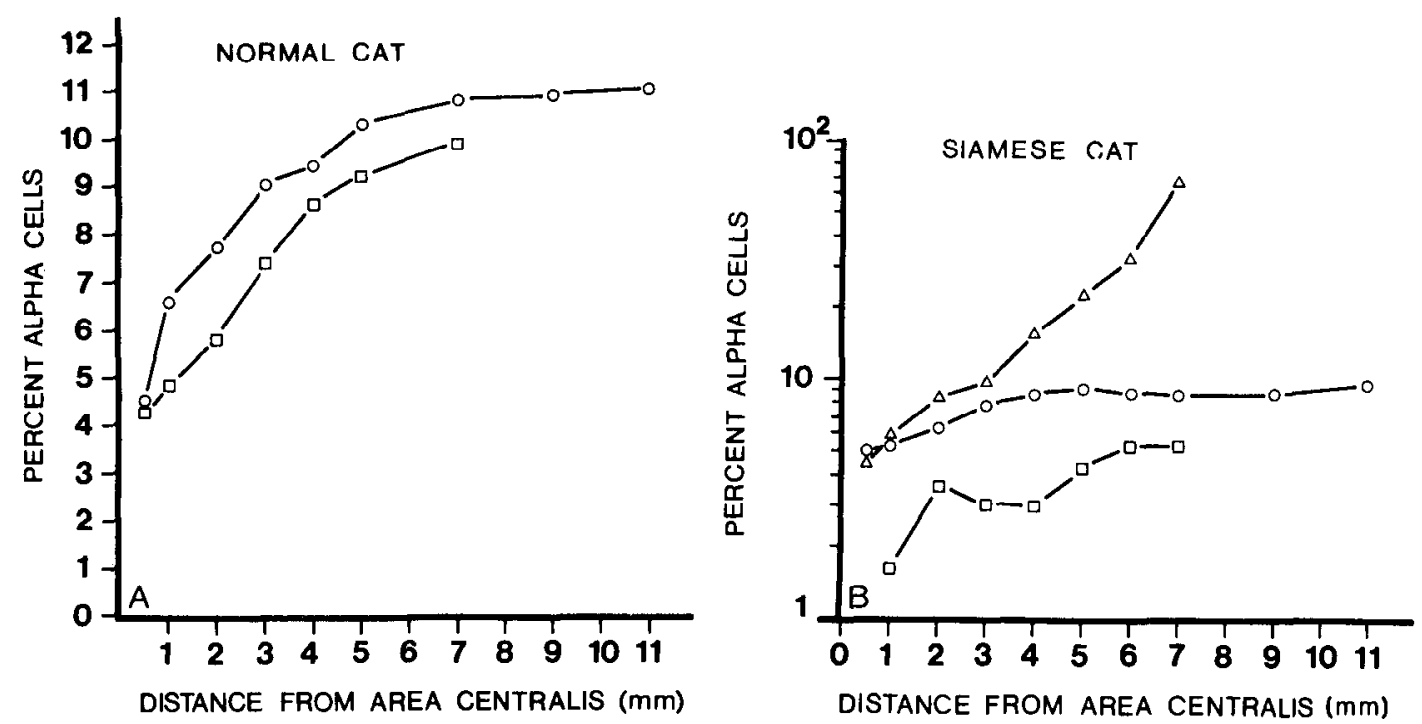

Figure 6. Percentages of $\alpha$ cells projecting to the A laminae in normal and Siamese cats. $A$, The percentages of $\alpha$ cells (number of labeled $\alpha$ cells/number of labeled $\alpha+\beta$ cells) projecting to lamina $\mathrm{Al}$ (D) and lamina A (O) of normal cat UC16. Outside of the area centralis, $\alpha$ cells constitute a larger proportion of the cells projecting to lamina A than to lamina A1. B, The percentages of $\alpha$ cells projecting to lamina $A(O)$, the normal segment of lamina $A 1(\square)$, and the abnormal segment of lamina A1 $(\Delta)$ of Siamese cat S5. $\alpha$ cells constitute an abnormally large proportion of the cells projecting to the abnormal segment of lamina Al and an abnormally small proportion of the cells projecting to the normal segment of lamina A1.

cells projecting to lamina $\mathrm{A} 1$ were also larger than the dendritic fields of those projecting to lamina A (Fig. $8 A$ ).

Dendritic coverage factor. The results presented thus far indicate the spatial densities as well as the dendritic field diameters of geniculate-projecting $\alpha$ and $\beta$ cells. With this information, it is possible to estimate the coverage of the retina by $\alpha$ and $\beta$ cells projecting to regions of the $A$ laminae subserving different parts of the visual field. The coverage factors for $\alpha$ and $\beta$ cells presented in Figure 9 were derived, for eccentricity, using the equation: coverage factor $=$ dendritic field area $\times$ density of cells. The coverage factors derived in this fashion indicate how many dendritic fields subserve a single point on the retina. Since the coverage factor increases as the dendritic field diameter and spatial density increase, the estimated coverage factors in Figure 9 may be somewhat low as there is no way of knowing whether all cells projecting to a given region were labeled by the HRP injections or whether the dendritic fields upon which Figure 9 is based were completely filled. However, it is likely that the present estimates are reasonable since both the spatial densities of labeled $\alpha$ and $\beta$ cells as well as the sizes of their dendritic fields are compatible with the estimates of others (Boycott and Wässle, 1974; Stone, 1978; Stone and Keens, 1980; Wässle et al., 1981).

In normally pigmented cats, the coverage of the retina by A laminae-projecting $\alpha$ cells is about 5 and remains constant across the retina. The coverage of the retina by
A laminae-projecting $\beta$ cells, on the other hand, decreases sharply over the central 3 to $4 \mathrm{~mm}$ of the retina and then remains constant in more peripheral regions. The coverage factors for $\beta$ cells range from about 11 at $0.5 \mathrm{~mm}$ from the area centralis to about 3.5 in the periphery.

$C$ laminae. In normally pigmented cats, the morphological classes of retinal ganglion cells projecting to the C laminae (laminae C, C1, and C2; Hickey and Guillery, 1974) include $\alpha, \beta, \epsilon, \gamma, \mathrm{g} 1$, and g2 cells (Fig. 10).

Because the $C$ laminae are much narrower than the $A$ laminae and are adjacent to the optic tract, it has not been possible to inject HRP into multiple sites within individual $\mathrm{C}$ laminae. Thus, it has not been possible in this study to quantify the ganglion cell inputs to individual C laminae. Nevertheless, the ganglion cell inputs to lamina $\mathrm{C} 1$ can be differentiated from those projecting to laminae $\mathrm{C}$ and $\mathrm{C} 2$. This is because cells projecting to lamina $\mathrm{C} 1$ effectively account for all labeled cells in the ipsilateral temporal retina following injections involving all of the $\mathrm{C}$ laminae. In view of this, the present results indicate that $\alpha$ and $\beta$ cells do not project to lamina $\mathrm{C} 1$ since these cell types are only found in the contralateral nasal retina as a result of injections involving all of the $\mathrm{C}$ laminae. On the other hand, $\epsilon, \mathrm{g} 1, \mathrm{~g} 2$, and $\gamma$ cells are found in the ipsilateral temporal retina as well as in the contralateral nasal retina as a result of these injections. Thus, these cell types apparently project to the ipsilateral as well as contralateral C laminae.

It is possible that some of the $\alpha$ and $\beta$ cells in the

of $\alpha$ (open symbols) and $\beta$ (solid symbols) cells labeled by HRP injections into the normal and abnormal segments of lamina A1 of Siamese cat S5. The squares represent cells in the ipsilateral temporal retina projecting to the normal segment of lamina A1. The triangles represent cells in the contralateral temporal retina projecting to the abnormal segment of lamina A1. The numbers of $\alpha$ and $\beta$ cells projecting to the abnormal segment of lamina Al decrease sharply with distance from the area centralis; the numbers of $\alpha$ and $\beta$ cells projecting to the normal segments of lamina A1 increase with distance from the area centralis over the central 4 to $5 \mathrm{~mm}$ of temporal retina. 

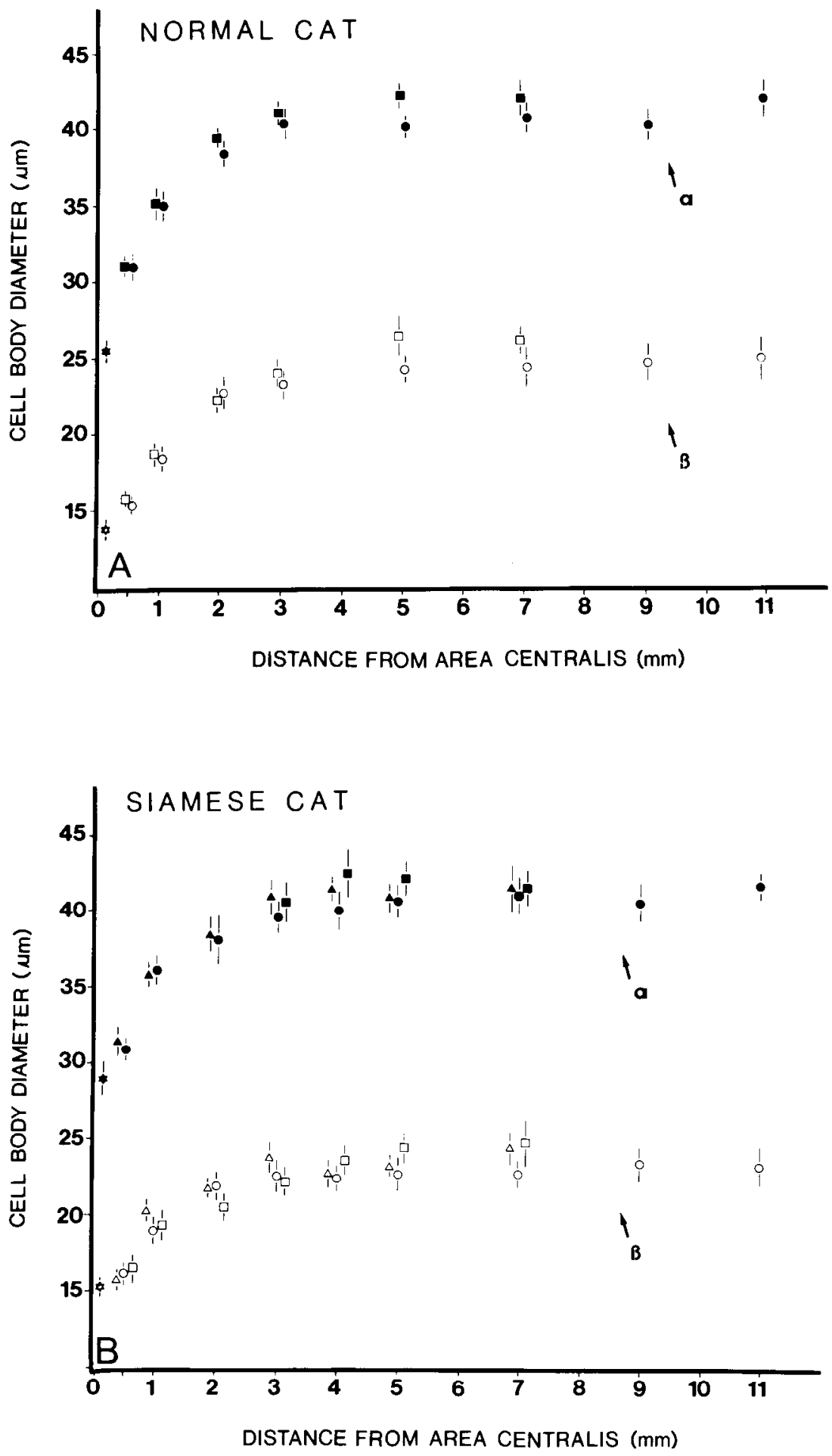

Figure 7. Cell body sizes of $\alpha$ and $\beta$ cells projecting to the A laminae in normal and Siamese cats. $A$, Cell body diameters of $\alpha$ (solid symbols) and $\beta$ (open symbols) cells projecting to laminae $A$ and $A 1$ of the LGNd of normal cat UC16. The squares indicate means for cells in the ipsilateral temporal retina projecting to lamina Al. The circles indicate means for cells in the contralateral nasal retina projecting to lamina $\mathrm{A}$. The stars indicate means for cells located between 0 and $0.5 \mathrm{~mm}$ from the center of the area centralis. Data for these points came from animals that received injections into the medialmost portion of the A laminae. Thus, the MIN may have been involved in the injection site (see text). Standard deviations are indicated by the lines through the symbols. $B$, Cell body diameters of $\alpha$ (solid symbols) and $\beta$ (open symbols) cells projecting to laminae $A$ and $A 1$ of Siamese cat S5. The squares indicate means for cells in the ipsilateral temporal retina projecting to the normal segment of lamina A1. The circles indicate means for cells in the contralateral nasal retina projecting to lamina $\mathrm{A}$. The triangles indicate means for cells in the contralateral temporal retina projecting to the abnormal segment of lamina A1. The stars are as in $A$. Due to the abnormal decussation in Siamese cats, 10 to 20 well stained cells could not be obtained for all eccentricities. These points have been omitted. In corresponding regions of the retina more than $2 \mathrm{~mm}$ from the area centralis in normal and Siamese cats, $\alpha$ and $\beta$ cells projecting to lamina Al have larger cell bodies than do $\alpha$ and $\beta$ cells projecting to lamina $A$. contralateral nasal retina labeled by $\mathrm{C}$ laminae injections actually represent cells projecting only to lamina A whose axons have been damaged by the electrode. However, spuriously labeled cells are unlikely to account for all of the labeled $\alpha$ and $\beta$ cells since, in the present study, injections were made into anterior parts of the LGNd which represent the lower visual field. In this part of the nucleus, the regions of retina projecting to the $\mathrm{C}$ laminae are superior to those projecting to the A laminae. Thus, spuriously labeled cells projecting to the A layers should, for the most part, be below those labeled by the injection itself.
In one cat that received an injection involving the $\mathrm{C}$ laminae, labeling was good enough to estimate the relative numbers of the different cell types projecting ipsilaterally to the $C$ laminae. One hundred thirteen labeled cells were studied in the region of retina corresponding to the position of the receptive fields of the cells at the injection site. Of these cells, g1 comprised $69 \%, \epsilon$ comprised $15 \%$, g2 comprised $11 \%$, and $\gamma$ cells comprised $5 \%$.

\section{Siamese cats}

Cortical recordings. Electrode penetrations were made into areas 17 and 18 of the visual cortex of 2 of the 

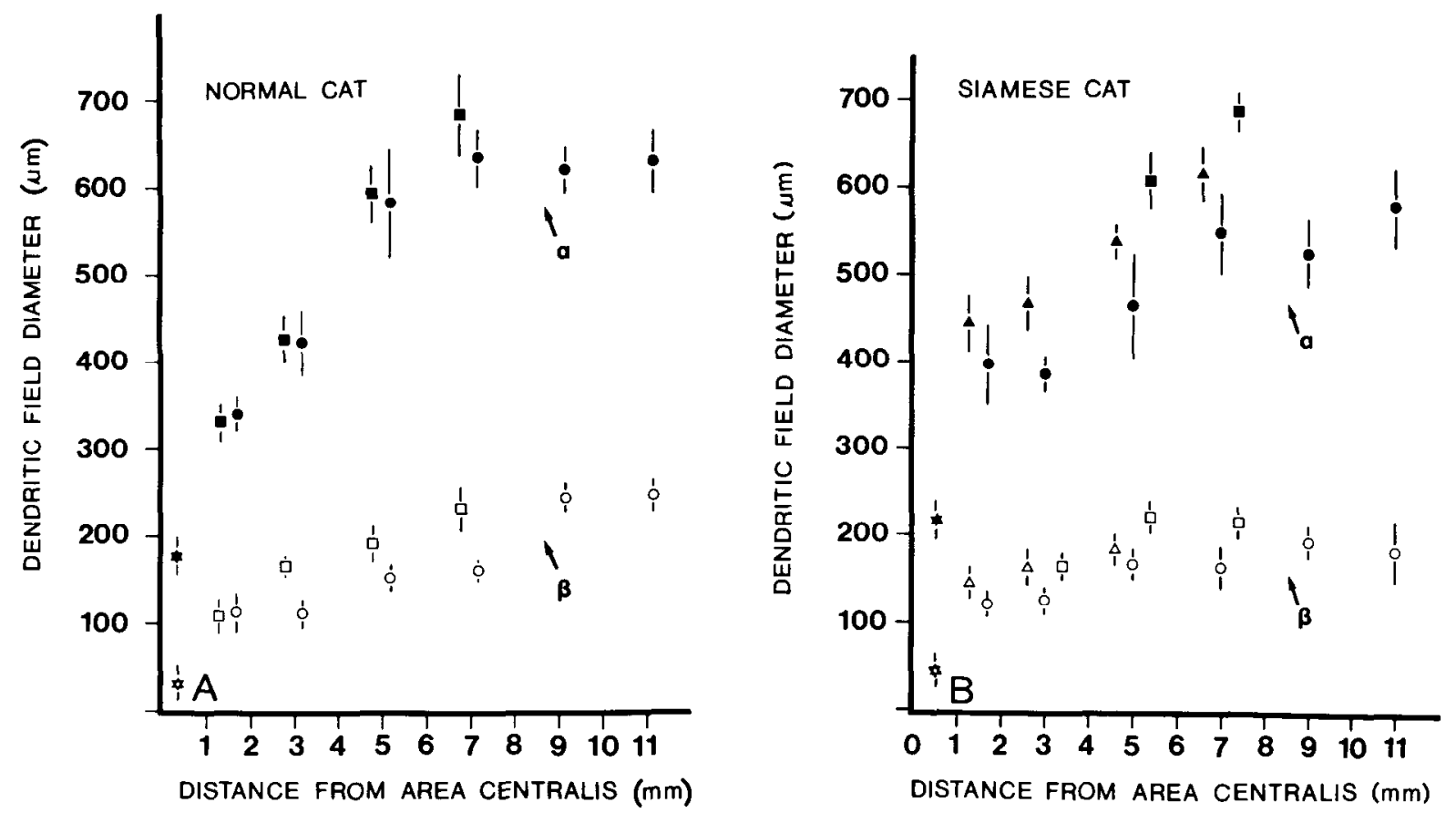

Figure 8. Dendritic field diameters of $\alpha$ and $\beta$ cells projecting to the A laminae in normal and Siamese cats. $A$, Dendritic field diameters of $\alpha$ (solid symbols) and $\beta$ (open symbols) cells projecting to laminae A and A1 of normal cat UC16. Conventions are as in Figure $7 A$. B, Dendritic field diameters of $\alpha$ (solid symbols) and $\beta$ (open symbols) cells projecting to laminae A and A1 of Siamese cat S5. Conventions as in Figure $7 B$. In corresponding regions of retina more than $2 \mathrm{~mm}$ from the area centralis in normal and Siamese cats, the dendritic fields of $\alpha$ and $\beta$ cells projecting to lamina A1 are larger than those for $\alpha$ and $\beta$ cells projecting to lamina A.

Siamese cats included in this study. One of these cats, S5, provided data for many of the figures in this section. Recordings from the region of the $17 / 18$ border in these animals suggested a "Boston" topography. That is, 15 to $20^{\circ}$ of the ipsilateral hemifield was represented in an orderly fashion in the region of the $17 / 18$ border (Hubel and Wiesel, 1971). In both animals, the receptive fields of the units encountered in areas 17 and 18 were located 5 to $10^{\circ}$ below the zero horizontal meridian. Since the regions of areas 17 and 18 which subserve the upper visual field were not studied, it remains possible that less of the ipsilateral hemifield was represented along the 17/ 18 border at higher elevations. Such regional variation has been reported recently by Cooper and Blasdel (1980).

A laminae. In order to study the retinal ganglion cell projection to the A laminae of Siamese cats, multiple injections of HRP were made into physiologically characterized sites as already described for normal cats. In Siamese cats, particular attention was paid to assure that the abnormal segment of lamina $\mathrm{Al}$, which receives inputs from ganglion cells in the contralateral temporal retina (Fig. 11), was involved in the injections. This part of lamina A1 is easily recognized since the receptive fields of its cells are in the ipsilateral hemifield, while the receptive fields of cells in lamina $A$ and the normal segments of lamina $\mathrm{Al}$ are in the contralateral hemifield. The spread of IIRP around the injection sites in Siamese cats extended medially almost to the border between the MIN and laminated IGNd and, thus, the medial normal segment of laminae A1 was likely to have been involved in the injection.

As a result of injections involving lamina $A$, the normal segments of lamina A1, or the abnormal segment of lamina A1 in Siamese cats, all labeled cells stained well enough to classify were either $\alpha$ (Fig. 2) or $\beta$ cells (Fig. $3)$. Thus, in Siamese cats, as well as in normally pigmented cats, it appears that only $\alpha$ and $\beta$ cells project to the A laminae.

The numbers of $\alpha$ and $\beta$ cells outside of the area centralis projecting to lamina $A$ appeared to be normal in the seal point Siamese cats included in this study (Fig. $5 B$ ). In the Siamese cat (S5) that provided the data for Figure $5, B$ and $C$, the peak density of labeled $\alpha$ cells in the contralateral nasal retina ranged from about 100 cells $/ \mathrm{mm}^{2}$ at $0.5 \mathrm{~mm}$ from the area centralis to about 7 cells $/ \mathrm{mm}^{2}$ at $11 \mathrm{~mm}$ from the area centralis (Fig. $5 B$ ). For $\beta$ cells, the peak densities ranged from about 2100 cells $/ \mathrm{mm}^{2}$ at $0.5 \mathrm{~mm}$ from the area centralis to about 70 cells $/ \mathrm{mm}^{2}$ at $11 \mathrm{~mm}$ from the area centralis (Fig. $5 B$ ).

The number of cells within the area centralis projecting to the Siamese A laminae could not be determined in this study since, following even very small injections centered in the most medial portion of the laminated LGNd, an involvement of the MIN in the injection site could not be ruled out. Consistent with the findings of Stone et al. (1978b), however, I have observed that the total number of Nissl-stained ganglion cells within the area centralis is abnormally low in Siamese cats.

Outside of the area centralis, the overall numbers of $\alpha$ and $\beta$ cells projecting to lamina A1 of cat S5 appeared normal (Fig. $5 B$ ). Of course, Siamese lamina $A 1$ receives inputs from the ipsilateral temporal retina as well as from the contralateral temporal retina. Thus, in order to determine the total number of cells projecting to Siamese lamina A1 in one hemisphere, it is necessary to combine the numbers of labeled $\alpha$ and $\beta$ cells in the temporal 

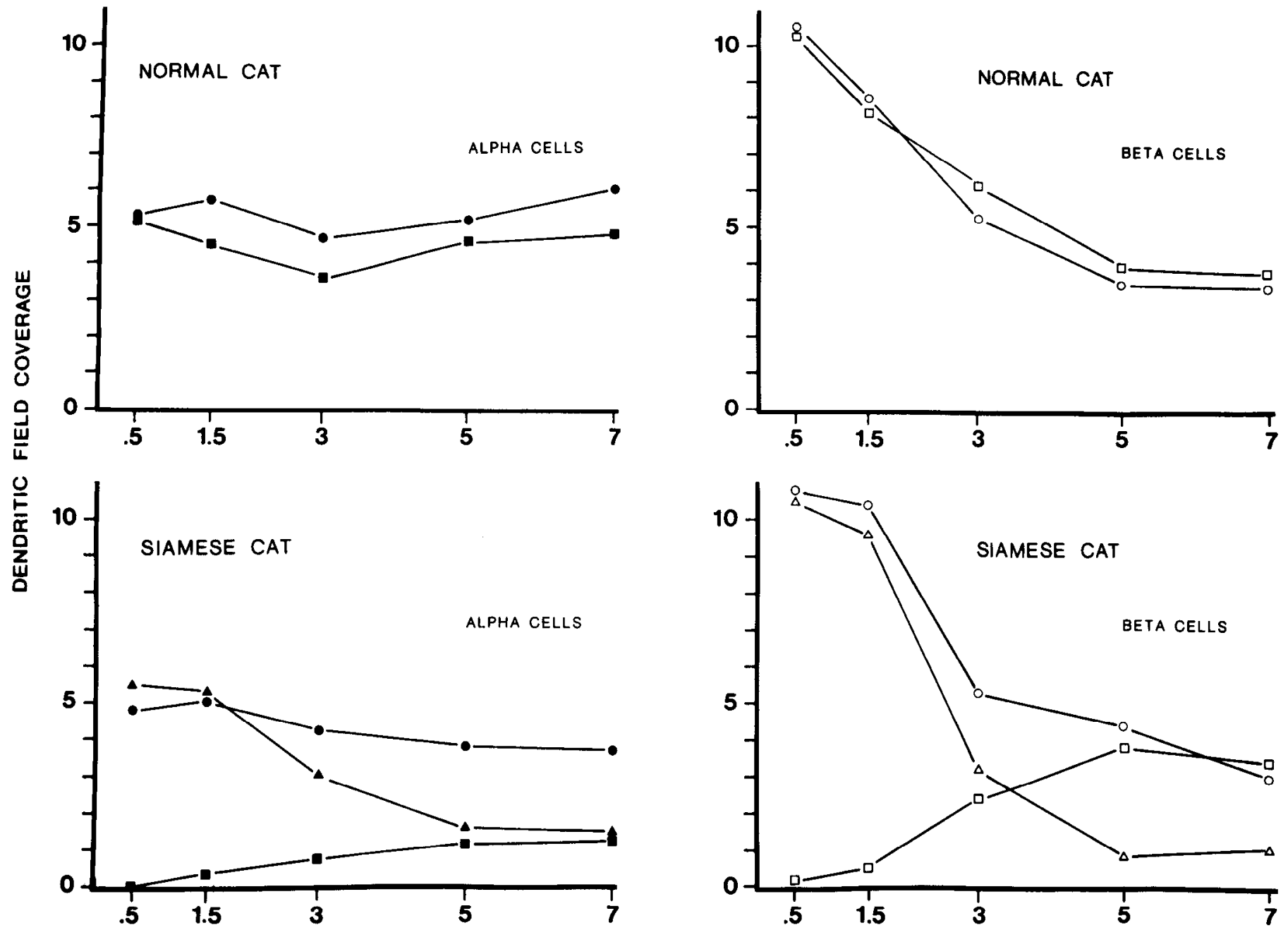

DISTANCE FROM AREA CENTRALIS

Figure 9. Coverage of the retina by the dendritic fields of $\alpha$ cells (solid symbols) and $\beta$ cells (open symbols) projecting to the LGNd in normal and Siamese cats. The circles, squares, and triangles represent values for cells in the contralateral nasal, ipsilateral temporal, and contralateral temporal retinas, respectively.

retinas of the two eyes following lamina A1 injections. The results of this analysis are shown in Figure $5 B$.

If the densities of labeled $\alpha$ and $\beta$ cells projecting to normal and abnormal segments of Siamese lamina A1 are not combined but rather are analyzed separately, the resulting values are grossly abnormal (Figs. $5 C, 11$, and 12).

In cat S5, the density of labeled $\alpha$ cells in the ipsilateral temporal retina resulting from injections involving the normal segments of lamina $A 1$ ranged from 0 cells $/ \mathrm{mm}^{2}$, or $0 \%$ of the $\alpha$ cells within $0.5 \mathrm{~mm}$ of the area centralis, to a maximum of 6 cells $/ \mathrm{mm}^{2}$, or about $50 \%$ of the $\alpha$ cells at 6 to $7 \mathrm{~mm}$ from the area centralis (Figs. $5 C$ and 12). The density of $\beta$ cells in the temporal retina projecting ipsilaterally to lamina AI ranged from 30 cells $/ \mathrm{mm}^{2}$, or about $1 \%$ of the $\beta$ cells at $0.5 \mathrm{~mm}$ from the area centralis, to a maximum of 165 cells $/ \mathrm{mm}^{2}$, or about $75 \%$ of the $\beta$ cells at $4 \mathrm{~mm}$ from the area centralis (Figs. $5 C$ and 12). The density of labeled $\beta$ cells then decreased to 70 cells/ $\mathrm{mm}^{2}$, or about $97 \%$ of the $\beta$ cells at $7 \mathrm{~mm}$ from the area centralis (Figs. $5 \mathrm{C}$ and 12 ).

Thus, in the temporal retina of Siamese cats, the proportions of both $\alpha$ and $\beta$ cells projecting ipsilaterally to lamina A1 increase with distance from the area centralis. This increase is more than sufficient to offset the normal decrease in the density of ganglion cells with increasing distance from the area centralis. The result is a situation never seen in normal cats. In particular, the parts of the normal segment of Siamese lamina A1 subserving the central retina apparently receive inputs from fewer ganglion cells than do the parts subserving the peripheral retina (Fig. $5 \mathrm{C}$ ). This is unlikely to be due to relatively little involvement of the medial portion of the LGNd in the injection site since the overall densities of labeled cells resulting from injections into Siamese lamina A1 (see above) appeared normal. Finally, the present experiments do not allow the ganglion cells projecting to the medial and lateral normal segments of lamina A1 to be differentiated since, typically, both regions were involved in the injection sites.

In cat S5, the density of labeled $\alpha$ cells in the contralateral temporal retina resulting from injections involving the abnormal segment of lamina $A 1$ ranged from 100 cells $/ \mathrm{mm}^{2}$, or $100 \%$ of the $\alpha$ cells at $0.5 \mathrm{~mm}$ from the area 
centralis, to 5 cells $/ \mathrm{mm}^{2}$, or about $50 \%$ of the $\alpha$ cells at 6 to $7 \mathrm{~mm}$ from the area centralis (Figs. $5 C$ and 12). The density of labeled $\beta$ cells in the contralateral temporal retina ranged from 2000 cells $/ \mathrm{mm}^{2}$, or about $99 \%$ of the $\beta$ cells at $0.5 \mathrm{~mm}$ from the area centralis, to 2 cells $/ \mathrm{mm}^{2}$, or about $3 \%$ of the $\beta$ cells at $7 \mathrm{~mm}$ from the area centralis (Figs. $5 C$ and 12 ).

Thus, in Siamese cats, the densities of labeled $\alpha$ and $\beta$ cells resulting from injections into parts of the abnormal segment of lamina A1 subserving the peripheral ipsilateral hemifield are much lower than the densities resulting from injections into regions subserving parts of the ipsilateral hemifield close to the vertical meridian. This decrease with eccentricity is much more dramatic than the normal decrease in the number of cells projecting to lamina A1 associated with eccentricity. This is because the proportion of contralaterally projecting cells in the temporal retina of Siamese cats decreases with distance from the area centralis and this decrease compounds the normal progressive decrease in the number of cells projecting to parts of lamina A1 subserving progressively more peripheral regions of retina.

In Siamese cat S5, the $\alpha / \beta$ ratios (number of labeled $\alpha$ cells/number of labeled $\alpha+\beta$ cells) that resulted from injections into different parts of lamina A1 increased from about 0.05 at $0.5 \mathrm{~mm}$ from the area centralis to about 0.10 at $4 \mathrm{~mm}$ from the area centralis. The $\alpha / \beta$ ratios remained constant at about 0.10 in more peripheral
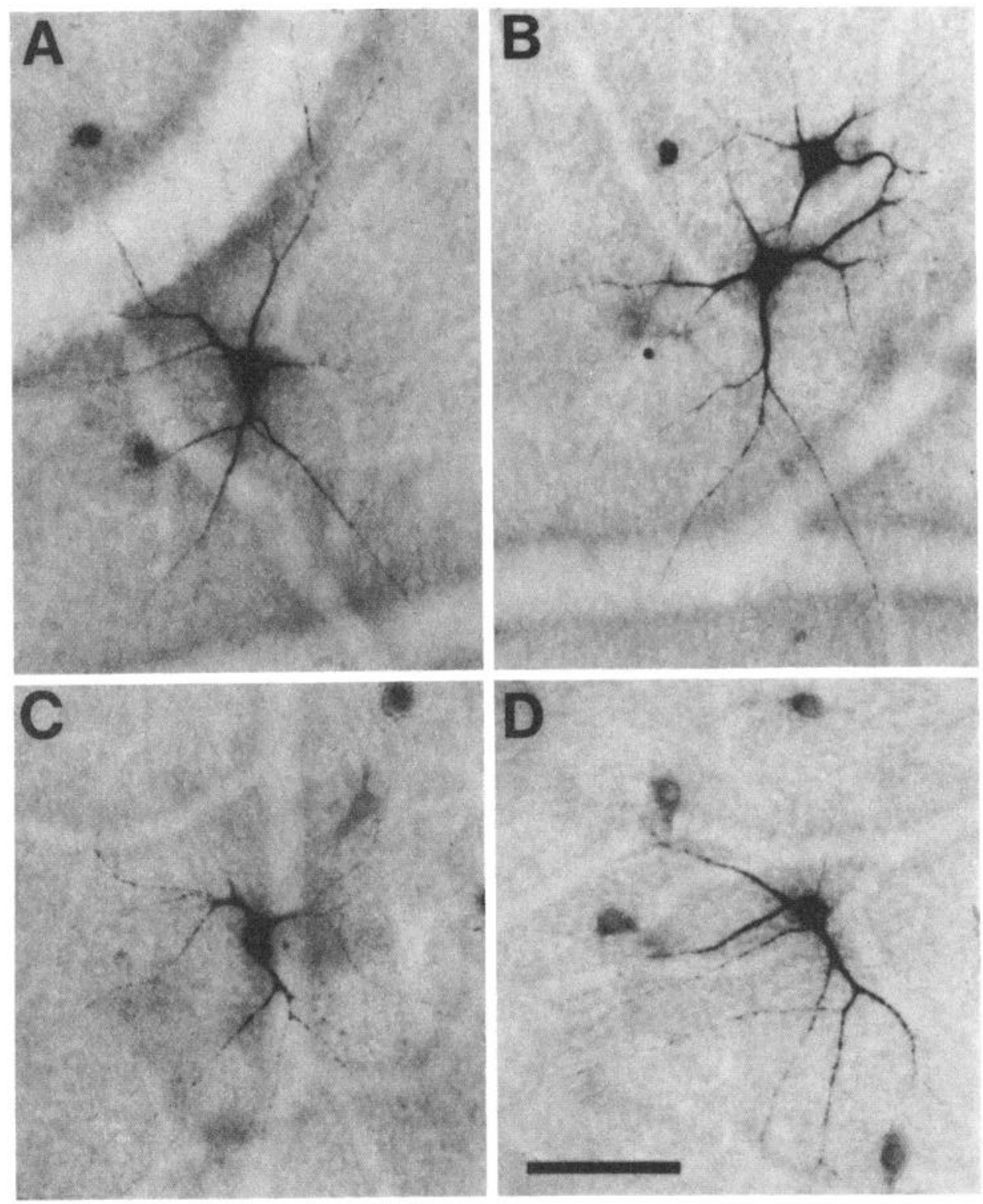

Figure 10. $\epsilon$ and g1 cells labeled by an injection of HRP involving the abnormal segment of lamina $\mathrm{C} 1$ of Siamese cat S3. The cells in $A$ to $D$ are all between 5 and $7 \mathrm{~mm}$ from the area centralis in the contralateral temporal retina. The cells with visible dendrites in $A$ and $B$ are $\epsilon$ cells. Those with visible dendrites in $C$ and $D$ are g1 cells. The cells shown in $A$ to $D$ are at the same magnification. Scale bar, $100 \mu \mathrm{m}$. $\epsilon$ and g1 cells projecting to the Siamese C laminae do not appear different from those projecting to the C laminae of normal cats. 


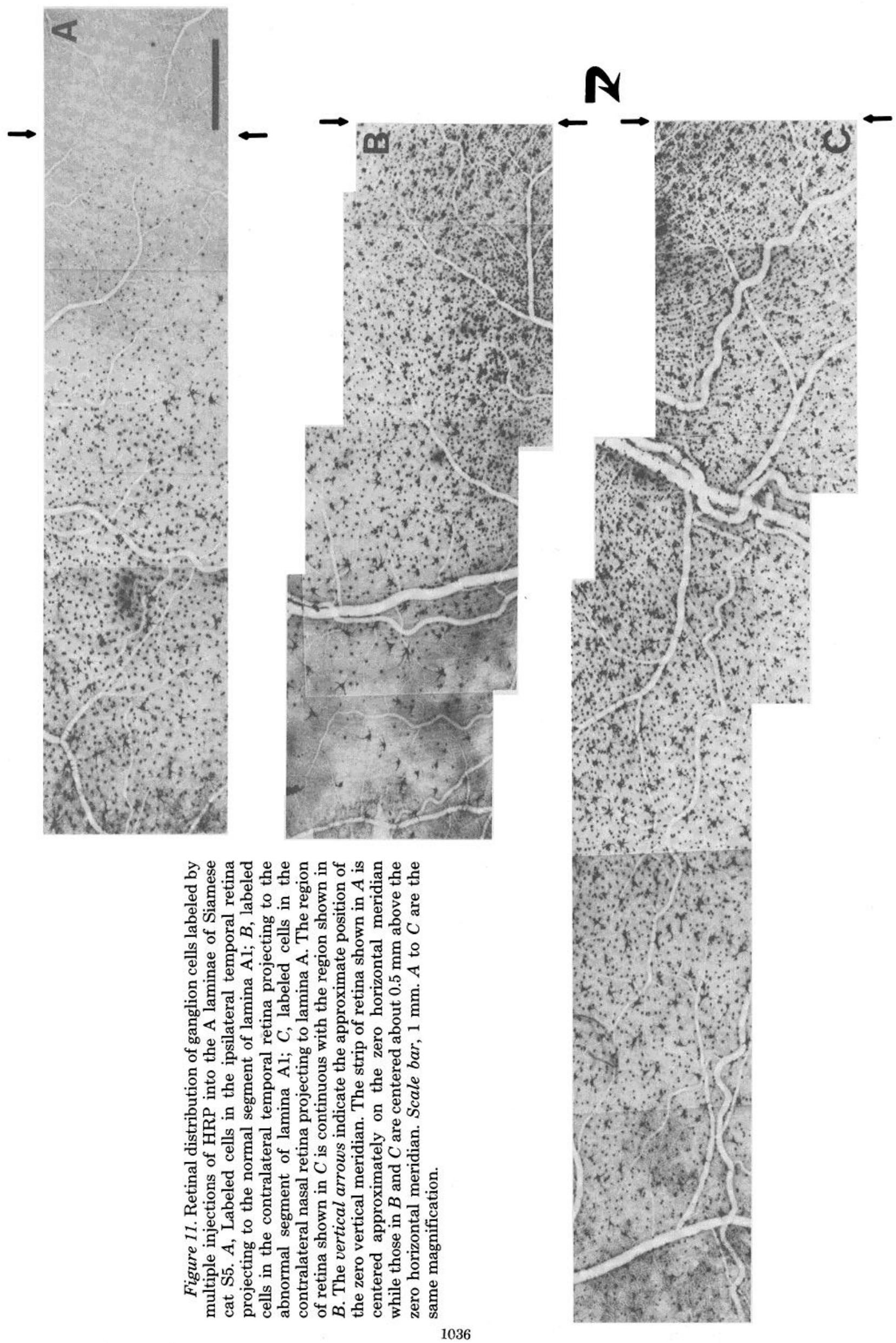




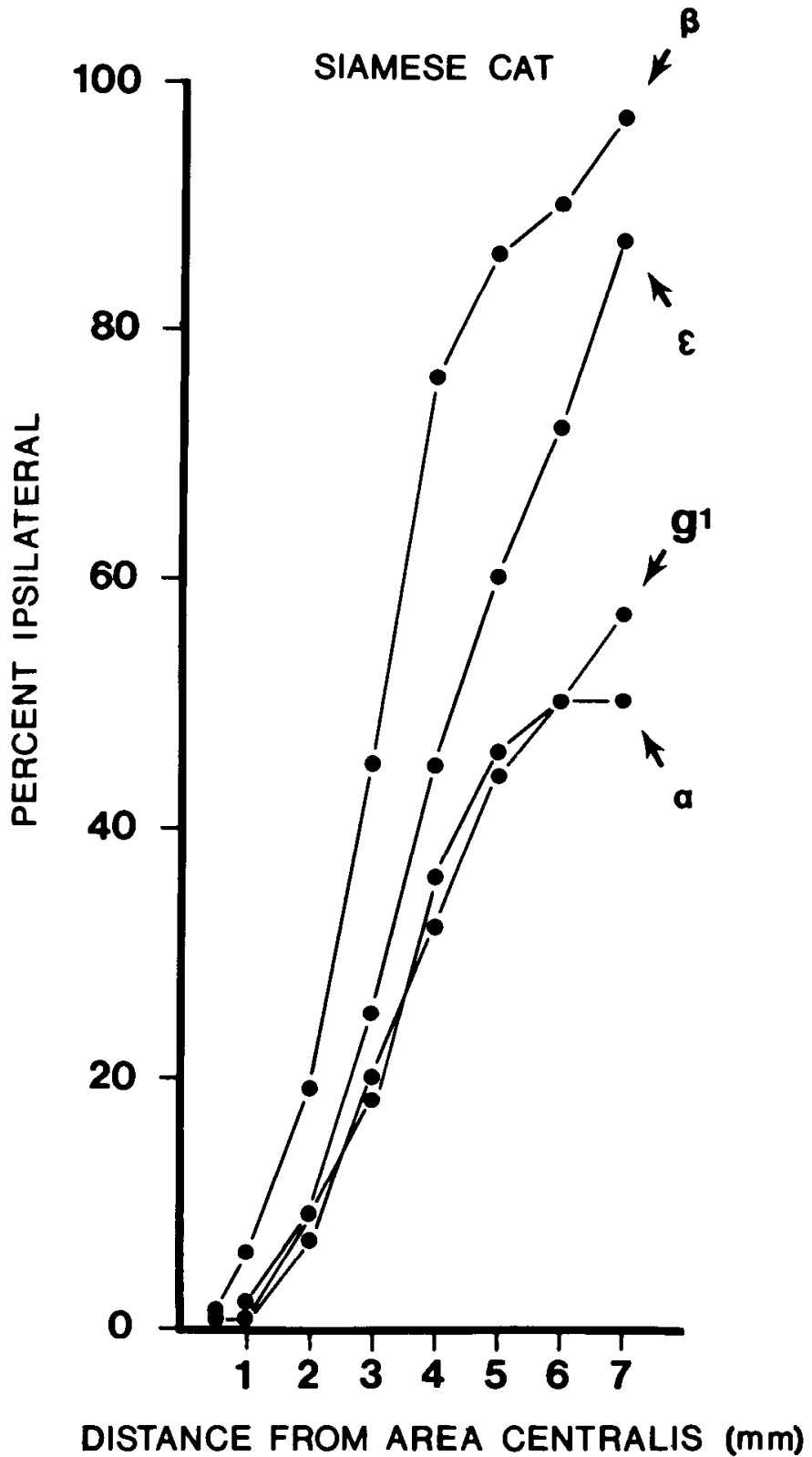

Figure 12. The percentages (number ipsilateral/number ipsilateral + number contralateral) of cells in the temporal retina which project to the ipsilateral LGNd in the Siamese cat. The values for $\alpha, \beta, \epsilon$, and 1 cclls are shown separately. These cell types account for over $90 \%$ of the ganglion cells projecting to the LGNd.

regions (Fig. $6 B$ ). These values are similar to those resulting from injections into lamina $A 1$ of normal cats (Fig. 6A).

The $\alpha / \beta$ ratios resulting from injections into the normal segments of lamina A1 of cat S5 were abnormally low. They ranged from 0 at $0.5 \mathrm{~mm}$ from the area centralis to only 0.04 at $7 \mathrm{~mm}$ from the area centralis (Fig. $6 B$ ). In marked contrast, the $\alpha / \beta$ ratios resulting from injections into the abnormal segment of lamina $\mathrm{A} 1$ were abnormally high. They ranged from 0.045 at $0.5 \mathrm{~mm}$ from the area centralis to over 0.7 at $7 \mathrm{~mm}$ from the area centralis (Fig. $6 B)$.

In Siamese cat S5, the cell bodies of $\alpha(p<0.025)$ and $\beta(p<0.05)$ cells in the temporal retina projecting to normal as well as abnormal segments of lamina A1 were larger than those projecting to lamina $\mathrm{A}$ (Fig. $7 B$ ). The dendritic fields (Fig. $8 B)$ of $\alpha(p<0.025)$ and $\beta(p<0.05)$ cells projecting to normal as well as abnormal segments of Siamese lamina A1 were also larger than the dendritic fields of their counterparts projecting to lamina A1. The cell bodies and dendritic fields of cells in the contralateral temporal retina projecting to the abnormal segment of lamina A1 were not obviously different from those of cells in corresponding regions of the ipsilateral temporal retina projecting to the normal segment of lamina $\mathrm{A} 1$ or from those of cells projecting to lamina A1 in normal cats.

The normal progressive increase in dendritic field size associated with retinal eccentricity does not appear to be as well developed in Siamese cats as in normal cats. In particular, while $\alpha$ and $\beta$ cells in the area centralis have smaller cell bodies and dendritic fields than $\alpha$ and $\beta$ cells in other regions of the Siamese retina, the dendritic fields of $\alpha(p<0.01)$ and $\beta(p<0.05)$ cells and cell bodies of $\alpha$ $(p<0.001)$ and $\beta(p<0.01)$ cells in and around the area centralis, but not in other parts of the retina, are larger in Siamese than in normal cats (Figs. 7 and 8). Similar results are obtained if cells in the area centralis of normal and Siamese cats receiving optic tract injections are compared (A. G. Leventhal, unpublished observations).

Dendritic coverage factor. In the Siamese cats in this study, the coverage of the contralateral nasal retina by $\alpha$ and $\beta$ cells projecting to lamina A appeared normal (Fig. 9). However, the coverage factors for $\alpha$ and $\beta$ cells projecting to normal and abnormal segments of lamina A1 were abnormally low.

The coverage of the contralateral temporal retina by $\alpha$ cells projecting to the abnormal segment of lamina A1 ranged from the normal value of about 5 in central retina to the abnormally low value of about 2.0 in the periphery. For $\beta$ cells projecting to the abnormal segment of lamina $A 1$, the coverage factors ranged from the normal value of about 11 near the area centralis to less than 1 in the periphery.

The coverage of the ipsilateral temporal retina by $\alpha$ cells projecting to the normal segment of lamina A1 ranged from nearly 0 within $3 \mathrm{~mm}$ of the area centralis to a maximum of only about 1.4 in the periphery. For $\beta$ cells projecting to the normal segment of lamina $\mathrm{A} 1$, the coverage factors ranged from almost 0 within $1.5 \mathrm{~mm}$ of the area centralis to the nearly normal value of about 3.5 in the far periphery.

The contralaterally innervated $C$ laminae (laminae $C$ and C2). The ganglion cell projection to the contralaterally innervated $\mathrm{C}$ laminae of Siamese cats appears normal. The evidence for this comes from the observation that, in normal and Siamese cats, the same types of ganglion cells are observed in the contralateral nasal retina as a result of injections involving laminae $\mathrm{C}$ and C2. These include $\alpha, \beta, \gamma, \epsilon$, g1, and g2 cells.

The ipsilaterally innervated C lamina (lamina C1). In Siamese cats, lamina $\mathrm{C} 1$ is similar to lamina $\mathrm{A} 1$ in that it receives afferents from the contralateral as well as from the ipsilateral temporal retinas, and thus, has abnormal and normal segments. As a result of injections into the Siamese C laminae, $\epsilon, \mathrm{g} 1$, g2, and $\gamma$ cells were observed in the ipsilateral temporal retina and in the contralateral 
temporal retina (Fig. 10). These types are the same as those found in the ipsilateral temporal retinas of normal cats following $\mathrm{C}$ laminae injections. Based upon this, it can be concluded that the same morphological types of ganglion cells project to lamina $\mathrm{C} 1$ in normal and Siamese cats and that all morphological types normally projecting to lamina $\mathrm{C} 1$ misproject in Siamese cats.

In normal cats, very few of the cells in the temporal retina which project to the $\mathrm{C}$ laminae project contralaterally. As already mentioned, this is not the case in Siamese cats. The proportions of $\epsilon$ and g1 cells in Siamese temporal retina projecting ipsilaterally to the $\mathrm{C}$ laminae are shown in Figure 12 for Siamese cat S3. For comparison, the corresponding values for $\alpha$ and $\beta$ cells projecting to lamina A1 of Siamese cat S5 also are shown. This figure shows that $\mathrm{g} 1$ and $\alpha$ cells have similar patterns of ipsilateral projection, while the pattern for $\epsilon$ cells is more similar to that of $\beta$ cells. As a result of this, relative to g1 cells, $\epsilon$ cells constitute an abnormally large proportion of the cells projecting to the normal segment of lamina $\mathrm{C} 1$ and an abnormally small proportion of cells projecting to the abnormal segment of $\mathrm{C} 1$.

Cells in ipsilateral nasal retina labeled by injections into the Siamese LGNd. In the present series of experiments, some labeled cells were consistently observed in the ipsilateral nasal retina following injections into the Siamese LGNd (see also Stone et al., 1978a). The density of these cells was never more than 3 or 4 cells $/ \mathrm{mm}^{2}$. A labeled $\alpha$ cell, located about $1.0 \mathrm{~mm}$ nasal to the area centralis of the ipsilateral retina of cat S5, is evident in Figure $11 A$. In 1 Siamese cat that received an injection into the C laminae, well stained cells were observed 10 $\mathrm{mm}$ from the zero vertical meridian in the ipsilateral nasal retina. The types of labeled cells observed in the ipsilateral nasal retinas of Siamese cats included $\alpha, \epsilon, \mathrm{g} 1$, g2, $\gamma$, and even an occasional $\beta$ cell.

Finally, it is worth mentioning that some types of cells, $\epsilon, \mathrm{g} 1, \mathrm{~g} 2$, and $\gamma$, also have been observed in the ipsilateral nasal retinas of normal cats that received injections into the optic tract. However, they were not as numerous, nor were they located as far into nasal retina, as in Siamese cats.

\section{Discussion}

The present results indicate that: (1) in Siamese and normal cats, the A laminae of the LGNd receive inputs from only $\alpha$ and $\beta$ ganglion cells, and the relative numbers of $\alpha$ and $\beta$ cells projecting to normal and abnormal segments of lamina A1 of Siamese cats are grossly abnormal; (2) in Siamese and normal cats, the contralateral $\mathrm{C}$ laminae (laminae $\mathrm{C}$ and $\mathrm{C2}$ ) together receive inputs from $\alpha, \beta, \gamma$, and $\epsilon$ cells as well as from other cell types referred to as g1 and g2 cells; (3) all classes of retinal ganglion cells which normally project ipsilaterally to the C laminae of the LGNd are affected by the Siamese abnormality; and (4) outside of the area centralis, the morphologies of the ganglion cells which project abnormally are not obviously different from those which project normally or from those in the normal cat.

Variability among animals. In both qualitative and quantitative terms, there was no significant variability among the normal animals studied. There was somewhat more variability among the Siamese cats studied. In particular, while qualitatively the same relationships reported here were found in all Siamese cats treated comparably, there were quantitative differences observed among animals (cf, Stone et al., 1978b; Cooper and Pettigrew, 1979b). In this study, these differences were minimized by including only seal point Siamese cats in the analysis. The seal point (S5) upon which many of the figures are based was typical of the seal points examined. S5 was chosen for illustration because of the exceptionally good staining of ganglion cells across both retinas.

Relationships among morphological and physiological classes of retinal ganglion cells. A number of lines of evidence indicate that the morphological classes $\alpha$ and $\beta$ correspond, respectively, to the physiological classes $Y$ and X (Boycott and Wässle, 1974; Cleland et al., 1975; Leventhal et al., 1980b). The functional identities of morphological types other than $\alpha$ and $\beta$, however, remain obscure. If all morphological classes other than $\alpha$ and $\beta$ are referred to collectively as $\gamma$ cells and all receptive field types other than $\mathrm{Y}$ and $\mathrm{X}$ are referred to collectively as $W$ cells, then of course, there is a correspondence between $\mathrm{W}$ cells and the cell types other than $\alpha$ and $\beta$ projecting to the LGNd C laminae. This correspondence, however, is one of definition.

There is already a significant body of evidence suggesting that there are, in fact, a number of physiological ganglion cell types other than $\mathrm{X}$ and $\mathrm{Y}$ (discussed in Rowe and Stone, 1977; Rodieck, 1979); this study extends previous ones in suggesting that there are a number of morphological types other than $\alpha, \beta$, and $\gamma . \epsilon$ cells (Leventhal et al., 1980a) and g1 cells, for example, differ quantitatively from $\alpha, \beta$, and $\gamma$ cells and have a unique pattern of central projection. $\epsilon$ and gl cells cannot be extreme examples of a continuum which includes $\gamma$ cells of the type illustrated by Boycott and Wässle (1974) since the central projections of these cell types and $\gamma$ cells differ markedly. $\epsilon$ and g1 cells project heavily to the retinal recipient zone of the pulvinar complex and to the LGNd C laminae, respectively, while $\gamma$ cells project mainly to the superior colliculus and pretectum (Leventhal et al., 1980b). If $\epsilon$ and g1 cells were simply medium sized $\gamma$ cells (Stone and Clarke, 1980), then the relative numbers of labeled small and medium size $\gamma$ cells should be the same following injections into all regions to which small $\gamma$ cells project. Since the proportions differ dramatically, $\epsilon$ and $\mathrm{g} 1$ cells must be considered distinct from the $\gamma$ cells illustrated by Boycott and Wässle (1974).

The distinction between $\epsilon$ and g1 cells can be made along the same lines since the relative number of these two cell types projecting to the retinal recipient zone (Leventhal et al., 1980a) and C laminae differ markedly. $\epsilon$ cells comprise the bulk of the cells projecting to the retinal recipient zone, and g1 cells comprise the bulk of the medium size cells projecting to the C laminae. Finally, the present results do not provide strong evidence that $\gamma$ and g2 cells have distinct patterns of central projection. Thus, the distinction between these cells and $\gamma$ cells is based only upon the dendritic branching patterns in HRP material. Further studies of the central projections of different morphological and physiological ganglion cell types are needed to develop a comprehensive classifica- 
tion of retinal ganglion cells and to determine the relationships among the various cell types (see also Rowe and Stone, 1977; Rowe and Dreher, 1982).

Cell body size and morphological class. It has become accepted by many that the size of a ganglion cell's soma provides an indication of its morphological type. It has been suggested that, in Nissl- as well as HRP-stained materials, small cells are $\gamma$ cells, medium size cells are $\beta$ cells, and large cells are $\alpha$ cells (Kelly and Gilbert, 1975; Wässle and Illing, 1980; Wässle et al., 1981). The present results indicate that cell body size alone is a poor indicator of morphological type for all but the largest $(\alpha)$ ganglion cells. In particular, the group of ganglion cells with medium size somas includes $\epsilon, \beta$, and g1 cells, while the group of cells with small cell bodies includes $\gamma$ as well as g2 cells. A significant degree of morphological diversity is also evident among Golgi-stained medium and small size cat ganglion cells (Stone and Clarke, 1980; Kolb et al., 1981).

Wässle et al. (1981) recently have reported that large HRP injections into the LGNd label all medium size retinal ganglion cells. These authors assumed that all of these medium size cells were $\beta$ cells and suggested that $\beta$ cells comprised $55 \%$ of cat ganglion cells. Since many of the medium size cells projecting to the cat's LGNd are not $\beta$ cells, Wässle et al.'s estimate is too high. The present results indicate that about $20 \%$ of the medium size ganglion cells projecting to the laminated LGNd are not $\beta$ cells. Thus, $\beta$ cells probably account for between 40 and $45 \%$ of cat ganglion cells.

The Siamese abnormality and retinal ganglion cell class. It has been suggested that $\alpha$ cells are more seriously affected by the Siamese abnormality than are other morphological types. The evidence for this comes from studies which have shown that, in the temporal retina of Siamese cats, the percentage of contralaterally projecting giant ganglion cells is higher than the overall percentage of contralaterally projecting cells (Stone et al., 1978a; Cooper and Pettigrew, 1979b).

The present results are in agreement with the empirical findings of these authors. However, in this study, it has been possible to determine the nasotemporal divisions of a number of cell types in addition to $\alpha$. This additional information suggests that $\alpha$ cells are not the most seriously affected cell type. In Siamese temporal retina, the percentages of contralaterally projecting $\mathrm{g} 1$ and $\alpha$ cells are similar. When compared to $\mathrm{g} 1$ and $\alpha$ cells, a lower proportion of $\beta$ and $\epsilon$ cells in the temporal retina project contralaterally.

It should be pointed out that the relative differences in the nasotemporal divisions of the different classes in the Siamese cat actually parallel those already present in the normal cat. In the normal cat, for example, the nasotemporal division for $\alpha$ cells is temporal to that for $\beta$ cells (Stone and Fukuda, 1974; Cooper and Pettigrew, $1979 a)$ and the nasotemporal divisions of $g 1$ and $\beta$ cells are similar to those of $\alpha$ and $\epsilon$ cells, respectively (Leventhal et al., 1980a; A. G. Leventhal, unpublished observations). In view of this, it appears that $\alpha$ cells are not differentially affected in Siamese cats. Rather, all classes appear to be affected and the differences among classes seen throughout the temporal retina in Siamese cats actually reflect differences already evident within approximately $1 \mathrm{~mm}$ of the area centralis in the temporal retina in normal cats.

Chino et al. (1978) have reported that the proportion of $\mathrm{Y}$ cell axons in the Siamese optic tract is abnormally low. The present results are difficult to reconcile with this finding since the overall numbers of $\alpha$ cells in all regions of Siamese retina studied appeared normal.

Differences between ganglion cells in nasal and temporal retina. In the normal cat, $\alpha$ and $\beta$ cells in the temporal retina project ipsilaterally and have larger cell bodies (see also Stone et al., 1980) and dendritic fields than contralaterally projecting $\alpha$ and $\beta$ cells in corresponding regions of the nasal retina.

In Siamese cats, differences between cells in the nasal and temporal retina also were observed. Moreover, in Siamese cats, no morphological differences were evident between cells in temporal retina which project ipsilaterally and those which project contralaterally. This suggests that the differences which were observed were due to the cell's location in the nasal or temporal retina, not to whether the cells projected ipsilaterally or contralaterally.

It is interesting to note that Friedlander et al. (1981) recently have reported that $\mathrm{Y}$ and $\mathrm{X}$ cells in lamina $\mathrm{A} 1$ of normal cats are larger than their counterparts in lamina A. Thus, at least some of the differences between nasally and temporally located $\alpha$ and $\beta$ cells seem to be paralleled by differences between the LGNd Y and X cells to which these cells presumably project. The functional significance, if any, of these morphological differences in the retina and LGNd remains to be determined.

Retinal abnormalities in Siamese cats. Outside of the area centralis, the morphologies and overall numbers of cells projecting to the LGNd of the seal point Siamese cats in this study appeared normal. Within the area centralis, a number of differences between normal and Siamese cats were observed consistently. First, the density of cells within the area centralis of the Siamese cat appears reduced. This finding is in agreement with that of Stone et al. (1978b). Second, the normal decrease in the sizes of the cell bodies and dendritic fields of $\alpha$ and $\beta$ cells in the area centralis was less pronounced in Siamese than in normal cats; the cell bodies and dendritic fields of $\alpha$ and $\beta$ cells in the Siamese area centralis were larger than those of $\alpha$ and $\beta$ cells in the normal area centralis.

Factors controlling ganglion cell size. Virtually all of the differences in the morphology of $\alpha$ and $\beta$ cells in different parts of the retina can be accounted for by assuming that, for these cell types, size is related inversely to ganglion cell density. The evidence for this is that: (1) the sizes of the cell bodies and dendritic fields of $\alpha$ and $\beta$ cells increase with distance from the area centralis, and the overall density of retinal ganglion cells decreases with distance from the area centralis; (2) the cell bodies and dendritic fields of $\alpha$ and $\beta$ cells in the temporal retina are larger than those of $\alpha$ and $\beta$ cells in the nasal retina, and the overall density of ganglion cells is greater in corresponding regions of the nasal than temporal retina (Stone, 1978); (3) $\alpha$ and $\beta$ cells in the area centralis of the Siamese cat have larger cell bodies 
and dendritic fields than do $\alpha$ and $\beta$ cells in the area centralis of the normal cat and the overall density of cells in the Siamese area centralis is less than in the normal area centralis.

Relative numbers of $Y$ and $X$ cells in the retina and $L G N d$. It has already been pointed out that $\alpha$ and $\beta$ cells are likely to correspond to $\mathrm{Y}$ and $\mathrm{X}$ cells, respectively. Assuming that these correspondences are correct, then the relative numbers of $\alpha$ and $\beta$ cells projecting to the $\mathrm{A}$ laminae of the LGNd provide a direct indication of the relative numbers of $\mathrm{Y}$ and $\mathrm{X}$ cells projecting to these layers.

In the normal cat, the A laminae of the LGNd receive inputs only from $\mathrm{Y}$ and $\mathrm{X}$ ganglion cells (Hoffmann et al., 1972), and the proportion of Y LGNd relay cells increases by a factor of about 2.3 (from about 30 to $70 \%$; Hoffmann et al., 1972) between regions representing central and far peripheral regions of the retina. The present results indicate that the number of $\alpha$ cells relative to $\beta$ cells projecting to the A laminae increases by a similar factor of about 2.4 (from 4.5 to $11 \%$ ) between corresponding regions. Thus, the numbers of LGNd $Y$ and $X$ cells receiving inputs from individual $\alpha$ and $\beta$ cells, respectively, may remain constant throughout the A laminae.

It is difficult to estimate the number of $Y$ cells relative to $X$ cells present in the LGNd A laminae since the extracellular microelectrodes used to study LGNd relay cells may record large cells selectively and LGNd Y cells are larger than LGNd X cells. Nevertheless, there is little doubt that the number of $Y$ cells relative to $X$ cells in the A laminae of the LGNd is higher than the number of $\alpha$ cells relative to $\beta$ cells projecting to these layers. Even So and Shapley's (1979) lowest estimate (obtained with high impedance micropipettes) of the proportion of $Y$ cells in the A laminae is about 3 times the proportion of $\alpha$ cells projecting to the A laminae. Moreover, estimates based upon neuroanatomical studies place the proportion of $\mathrm{Y}$ cells in the A laminae at $35 \%$ (Friedlander et al., 1981 ) and $50 \%$ (Levay and Ferster, 1977). In view of this, the relative numbers of $\alpha$ and $\beta$ cells projecting to the A laminae suggest, in agreement with Friedlander et al. (1981), that one function of the A laminae is to "amplify" the $\mathrm{Y}$ system relative to the $\mathrm{X}$ system.

In the normal cat, the number of $Y$ relay cells relative to $\mathrm{X}$ relay cells is greater in lamina $\mathrm{A} 1$ than in lamina $\mathrm{A}$ (Wilson et al., 1976). However, the present findings indicate that the number of $\alpha$ cells relative to $\beta$ cells is greater for cells projecting to lamina $A$ than to lamina A1. Hence, it appears that there is greater amplification of the $\mathrm{Y}$ system relative to the $\mathrm{X}$ system for cells projecting to lamina $A 1$ (the ipsilateral pathway) than for cells projecting to lamina A (the contralateral pathway).

Dendritic coverage factors. As noted above, the number of Y relay cells relative to X relay cells in the LGNd differs significantly from the number of $\alpha$ cells relative to $\beta$ cells in the retina. However, the number of LGNd Y cells relative to LGNd X cells is similar to the ratios of the coverage factors for $\alpha$ and $\beta$ cells projecting to the LGNd. In particular, the proportion of coverage by $\alpha$ cells ( $\alpha$ coverage $/ \alpha+\beta$ coverage) ranges from about 0.33 at $0.5 \mathrm{~mm}$ from the area centralis to about 0.56 at $7 \mathrm{~mm}$ from the area centralis (Fig. 13). These values are com-

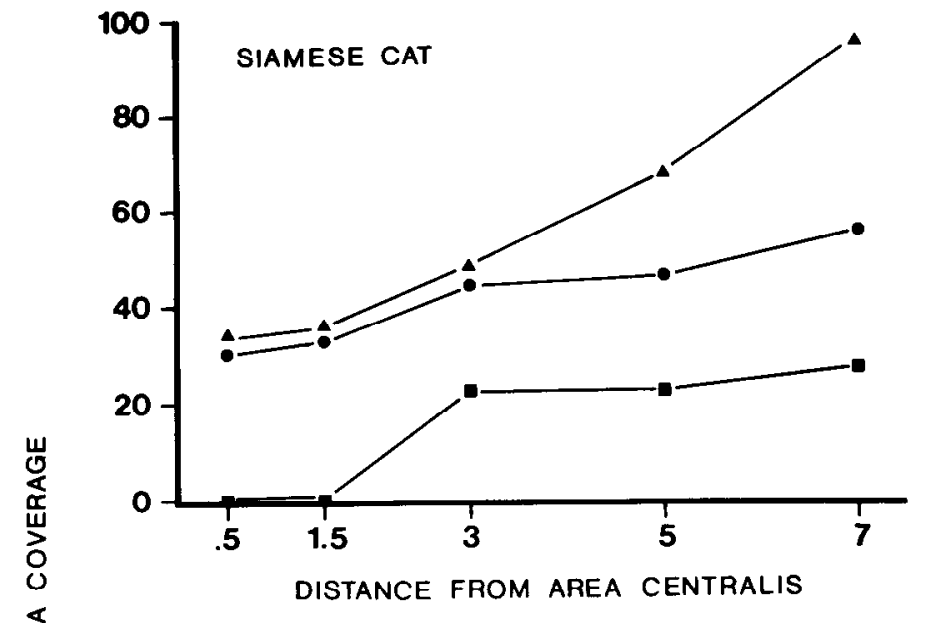

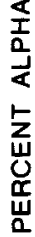

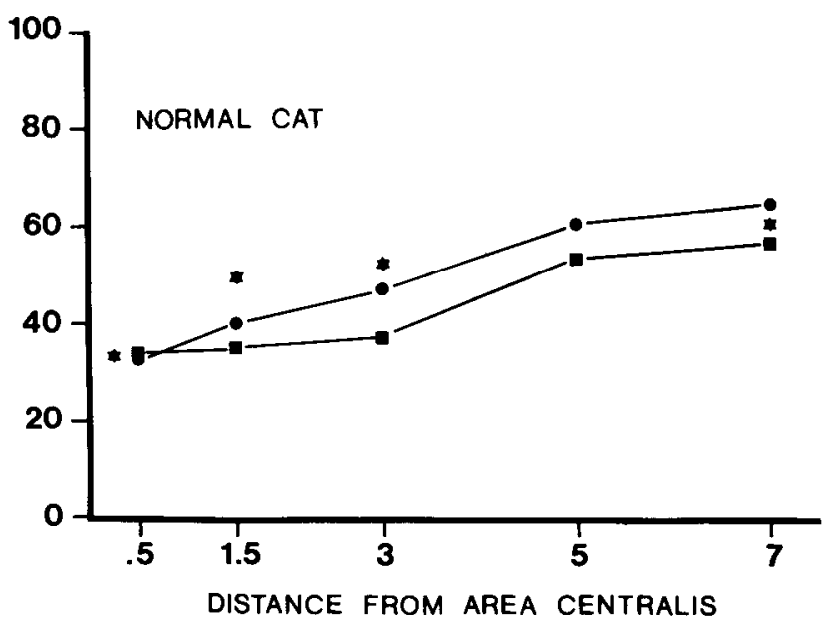

Figure 13. Percentage of $\alpha$ coverage ( $\alpha$ coverage/ $\alpha$ coverage $+\beta$ coverage) for $\alpha$ and $\beta$ cells projecting to the A laminae of normal and Siamese cats. The circles, squares, and triangles represent values for contralateral nasal, ipsilateral temporal, and contralateral temporal retinas, respectively. The stars indicate the approximate percentage of $Y$ cells encountered during physiological studies of the normal cat's A laminae (from Hoffmann et al,, 1972). Degrees of eccentricity in that study were converted to millimeters from the area centralis assuming that $1 \mathrm{~mm}$ of cat retina subtends $4.4^{\circ}$ of visual angle. Notice that, in the normal cat, the percentage of $\alpha$ coverage corresponds closely, at each eccentricity, to the percentage of $Y$ cells in the A laminae.

patible with most estimates (discussed above) of the numbers of $\mathrm{Y}$ cells relative to $\mathrm{X}$ cells in the A laminae. Therefore, it seems that the number of $Y$ cells relative to $X$ cells in the LGNd reflects the coverage of the retina by LGNd-projecting $\alpha$ and $\beta$ cells, not the spatial densities of their cell bodies. It may be that the LGNd is translating relative differences in retinal coverage into corresponding differences in the relative numbers of different types of relay cells.

It should be mentioned that the coverage of the retina by the receptive fields of $\mathrm{Y}$ and $\mathrm{X}$ cells differs somewhat from the dendritic coverage factors derived for $\alpha$ and $\beta$ cells. In particular, while the dendritic field sizes of $\alpha$ 
cells are consistent with the receptive field sizes of $\mathrm{Y}$ cells, $\beta$ cell dendritic fields appear to be smaller than the receptive field sizes of $X$ cells predict (Peichl and Wässle, 1979). If this difference is not artifactual, then the coverage of the retina by $X$ cell receptive fields may be somewhat greater than the measurements for $\beta$ cells indicate.

The coverage of the contralateral nasal retina by $\alpha$ and $\beta$ cells projecting to Siamese lamina $A$ appears to be normal. In contrast, the coverage of the ipsilateral and contraluteral temporal retinas by $\alpha$ and $\beta$ cells projecting, respectively, to normal and abnormal segments of lamina $\mathrm{A} 1$ are abnormally low. This may explain in part why Siamese temporal retina contributes so little to visual behavior (Elekessy et al., 1973).

Visual field representation in lamina A1 of Siamese cats. The present results indicate that ganglion cells projecting to lamina A1 are distributed continuously throughout both the ipsilateral and contralateral temporal retinas (Figs. 5C and 11; also see Stone et al., 1978a; Cooper and Pettigrew, 1979b). Thus, all of the ipsilateral and contralateral hemifields should be represented in Siamese lamina $\mathrm{A} 1$ and it is possible that both the normal and abnormal segments of lamina $\mathrm{A} 1$ receive some binocularly overlapping inputs.

Physiological studies of the Siamese A laminae indicate that the central 10 to $20^{\circ}$ of the ipsilateral temporal retina is not represented in the normal segments of lamina A1 and that regions of the contralateral temporal retina more than about $25^{\circ}$ from the zero vertical meridian are not represented in the abnormal segments of lamina A1. Moreover, cells throughout Siamese lamina A1 are activated monocularly (Guillery and Kaas, 1971). These physiological findings, taken together with the present anatomical ones, suggest that, in Siamese cats, the relatively weak inputs to lamina Al from the central, ipsilateral temporal, and peripheral, contralateral temporal retinas are suppressed.

\section{References}

Adams, J. C. (1977) Technical considerations on the use of horseradish peroxidase as a neuronal marker. Neuroscience 2: 141 .

Bowling, D. B., and C. R. Michael (1981) 'Termination patterns of single optic tract axons of different physiological types. Soc. Neurosci. Abstr. 7: 25.

Boycott, B. B., and H. Wässle (1974) The morphological types of ganglion cells of the domestic cat's retina. J. Physiol. (Lond.) 140: 397-419.

Chino, Y. M., M. S. Shansky, and D. I. Hamasaki (1978) Properties of X-and Y-type retinal ganglion cells in Siamese cats. Brain Res. 43: 459-473.

Cleland, B. G., M. W. Dubin, and W. R. Levick (1971) Sustained and transient neurones in the cat's retina and lateral geniculate nucleus. J. Physiol. (Lond.). 217: 473-496.

Cleland, B. G., W. R. Levick, and H. Wässle (1975) Physiological identification of a morphological class of cat retinal ganglion cells. J. Physiol. (Lond.). 248: 151-171.

Cleland, B. G., W. R. Levick, R. Morstyn, and H. G. Wagner (1976) Lateral geniculate relay of slowly conducting retinal afferents to cat visual cortex. J. Physiol. (Lond.) 255: 299-320.

Cooper, M. L., and G. G. Blasdel (1980) Regional variation in the representation of the visual field in the visual cortex of the Siamese cat. J. Comp. Neurol. 193: 237-254.
Cooper, M. L., and J. D. Pettigrew (1979a) The decussation of the retinothalamic pathway in the cat, with a note on the major meridians of the cat's eye. J. Comp. Neurol. 187: $285-312$.

Cooper, M. L., and J. D. Pettigrew (1979b) The retinothalamic pathways in Siamese cats. J. Comp. Neurol. 187: 313-348.

Creel, D. J. (1971a) Visual system anomaly associated with albinism in the cat. Nature 231: 465-466.

Creel, D. J. (1971b) Ipsi- and contralateral visually evoked responses in the cat: Strains compared. J. Comp. Physiol. Psychol. 77: 161-165.

Creel, D. J., and R. A. Giolli (1976) Retinogeniculate projections in albino and ocularly hypopigmented rats. J. Comp. Neurol. 166: 445-456.

Dreher, B., and A. J. Sefton (1979) Properties of neurons in cat's dorsal lateral geniculate nucleus: A comparison between medial interlaminar and laminated parts of the nucleus. J. Comp. Neurol. 183: 47-64.

Dreher, B., A. G. Leventhal, and P. T. Hale (1980) The geniculate input to cat visual cortex: A comparison of area 19 with areas 17 and 18. J. Neurophysiol. 44: 804-826.

Elekessy, E. I., J. E. Campion, and G. H. Henry (1973) Differences between the visual fields of Siamese and common cats. Vision Res. 13: 2533-2543.

Friedlander, M. H., C. S. Lin, L. R. Stanford, and S. M. Sherman (1981) Morphology of functionally identified neurons in lateral geniculate nucleus of the cat. J. Neurophysiol. 46: 80-129.

Guillery, R. W. (1969) An abnormal retinogeniculate projection in Siamese cats. Brain Res. 14: 739-741.

Guillery, R. W., and J. H. Kaas (1971) A study of normal and congenitally abnormal retinogeniculate projections in cats. J. Comp. Neurol. 143: 73-100.

Hanker, J. S., P. E. Yates, C. B. Meltz, and A. Rustioni (1977) A new specific sensitive and non-carcinogenic reagent for the demonstration of horseradish peroxidase. J. Histochem. $\mathrm{Cy}$ tochem. 9: 789-792.

Hickey, T. L., and R. W. Guillery (1974) An autoradiographic study of retinogeniculate pathways in the cat and fox. J. Comp. Neurol. 156: 239-254.

Hoffmann, K. P., J. Stone, and S. M. Sherman (1972) Relay of receptive-field properties in dorsal lateral geniculate nucleus of the cat. J. Neurophysiol. 35: 518-531.

Hubel, D. H., and T. N. Wiesel (1971) Aberrant visual projections in the Siamese cat. J. Physiol. (Lond.) 218: 33-62.

Kelly, J. P., and C. D. Gilbert (1975) The projections of different morphological types of ganglion cells in the cat retina. J. Comp. Neurol. 163: 65-80.

Kolb, H., R. Nelson, and A. Mariani (1981) Amacrine cells, bipolar cells and ganglion cells of the cat retina: A Golgi study. Vision Res. 21: 1081-1114.

LeVay, S., and D. Ferster (1977) Relay cell classes in the lateral geniculate nucleus of the cat and the effects of visual deprivation. J. Comp. Neurol. 172: 563-584.

Leventhal, A. G. (1979) Evidence that the different classes of relay cells of the cat's lateral geniculate nucleus terminate in different layers of the striate cortex. Exp. Brain Res. 37: 349-372.

Leventhal, A. G., and H. V. B. Hirsch (1978) Receptive field properties of neurons in different laminae of the visual cortex of the cat. J. Neurophysiol. 41: 948-962.

Leventhal, A. G., J. Keens, and I. Tork (1980a) The afferent ganglion cells and cortical projections of the retinal recipient zone of the cat's pulvinar complex. J. Comp. Neurol. 194: 535-554.

Leventhal, A. G., R. W. Rodieck, and B. Dreher (1980b) Morphology and central projections of different types of retinal ganglion cells in cat and old-world monkey ( $M$. fascicularis). Soc. Neurosci. Abstr. 6: 582. 
Leventhal, A. G., R. W. Rodieck, and B. Dreher (1981) Retinal ganglion cell classes in old world monkey: Morphology and central projections. Science 213: 1139-1142.

Lund, R. D. (1965) Uncrossed visual pathways of hooded albino rats. Science 149: 1506-1507.

Mason, R. (1975) Cell properties in the medial interlaminar nucleus of the cat's lateral geniculate nucleus in relation to the transient/sustained classification. Exp. Brain Res. 22: 327-329.

Mitzdorf, U., and W. Singer (1977) Laminar segregation of afferents to lateral geniculate nucleus of the cat: An analysis of current source density. J. Neurophysiol. 40: 1227-1244.

Peichl, L., and H. Wässle (1979) Size, scatter and coverage of ganglion cell receptive field centres in the cat retina. J. Physiol. (Lond.) 291: 117-141.

Rodieck, R. W. (1979) Visual pathways. Annu. Rev. Neurosci. 2: 193-225.

Rowe, M. H., and B. Dreher (1982) W cell projection to the medial interlaminar nucleus of the cat: Implications for ganglion cell classification. J. Comp. Neurol. 204: 117-133.

Rowe, M. H., and J. Stone (1977). Naming of neurones; classification and naming of cat retinal ganglion cells. Brain Behav. Evol. 14: 185-216.

Sheridan, C. L. (1965) Interocular transfer of brightness and pattern discriminations in normal and corpus callosum-sectioned rats. J. Comp. Physiol. Psychol. 59: 292-294.

So, Y. T., and R. M. Shapley (1979) Spatial properties of X and $Y$ cells in the lateral geniculate nucleus of the cat and conduction velocities of their inputs. Exp. Brain Res. 36: 533550.

Stanford, L. R., M. Sur, and S. M. Sherman (1981) Terminal morphology of physiologically identified X and Y optic tract axons within the lateral geniculate nucleus of the cat. Soc. Neurosci. Abstr. 7: 25.

Stone, J. (1978) The number and description of ganglion cells in the cat's retina. J. Comp. Neurol. 180: 753-773.

Stone, J., and R. Clarke (1980) Correlation between soma size and dendritic morphology in cat retinal ganglion cells. Evidence of further variation in the gamma-cell class. J. Comp. Neurol. 192: 211-217.

Stone, J., and Y. Fukuda (1974) The naso-temporal division of the cat's retina re-examined in terms of W-, X- and Y-cells. J. Comp. Neurol. 155: 377-394.

Stone, J., and J. Keens (1980) Distribution of small and medium sized ganglion cells in the cat's regina. J. Comp. Neurol. 192: 235-246.

Stone, J., J. E. Campion, and J. Leicester (1978a) The nasotemporal division of the retina in the Siamese cat. J. Comp. Neurol. 180: 783-798.

Stone, J., M. H. Rowe, and J. E. Campion (1978b) Retinal abnormalities in the Siamese cat. J. Comp. Neurol. 180: 773782.

Stone, J., B. Dreher, and A. G. Leventhal (1979) Parallel and hierarchical mechanisms in the organization of visual cortex. Brain Res. Rev. 1: 345-394.

Stone, J., A. G. Leventhal, C. R. R. Watson, J. Keens, and R. Clarke (1980) Gradients between nasal and temporal areas of the cat retina in the properties of retinal ganglion cell. $\mathrm{J}$. Comp. Neurol. 192: 219-235.

Wässle, H., and R. B. Illing (1980) The retinal projection to the superior colliculus in the cat: A quantitative study with HRP. J. Comp. Neurol. 190: 333-356.

Wässle, H., R. R. Boycott, and R. B. Illing (1981) Morphology and mosaic of on- and off-beta cells in the cat retina and some functional considerations. Proc. R. Soc. Lond. (Biol.) 212: 177-195.

Wilson, P. E., M. H. Rowe, and J. Stone (1976) Properties of relay cells in the cat's lateral geniculate nucleus. A comparison of W-cells with X-and Y-cells. J. Neurophysiol. 38: 11931209. 